\title{
Increased Synthesis of Chondroitin Sulfate Proteoglycan Promotes Adult Hippocampal Neurogenesis in Response to Enriched Environment
}

\author{
Jun Yamada, ${ }^{1}$ Satomi Nadanaka, ${ }^{2}$ Hiroshi Kitagawa, ${ }^{2}{ }^{\top}$ Kosei Takeuchi, ${ }^{3}$ and ${ }^{\oplus S h o z o ~ J i n n o ~}{ }^{1}$ \\ ${ }^{1}$ Department of Anatomy and Neuroscience, Graduate School of Medical Sciences, Kyushu University, Fukuoka 812-8582, Japan, ${ }^{2}$ Department of \\ Biochemistry, Kobe Pharmaceutical University, Kobe 658-8558, Japan, and ${ }^{3}$ Department of Medical Biology, School of Medicine, Aichi Medical University, \\ Nagakute 480-1195, Japan
}

Chondroitin sulfate proteoglycan (CSPG) is a candidate regulator of embryonic neurogenesis. The aim of this study was to specify the functional significance of CSPG in adult hippocampal neurogenesis using male mice. Here, we showed that neural stem cells and neuronal progenitors in the dentate gyrus were covered in part by CSPG. Pharmacological depletion of CSPG in the dentate gyrus reduced the densities of neuronal progenitors and newborn granule cells. 3D reconstruction of newborn granule cells showed that their maturation was inhibited by CSPG digestion. The novel object recognition test revealed that CSPG digestion caused cognitive memory impairment. Western blot analysis showed that expression of $\beta$-catenin in the dentate gyrus was decreased by CSPG digestion. The amount of CSPG in the dentate gyrus was increased by enriched environment (EE) and was decreased by forced swim stress. In addition, EE accelerated the recovery of CSPG expression in the dentate gyrus from the pharmacological depletion and promoted the restoration of granule cell production. Conversely, the densities of newborn granule cells were also decreased in mice that lacked chondroitin sulfate $\mathrm{N}$-acetylgalactosaminyltransferase 1 (CSGalNAcT1), a key enzyme for CSPG synthesis (T1KO mice). The capacity of EE to promote granule cell production and improve cognitive memory was impaired in T1KO mice. These findings indicate that CSPG is involved in the regulation of adult hippocampal neurogenesis and suggest that increased synthesis of CSPG by CSGalNacT1 may mediate promotion of granule cell production and improvement of cognitive memory in response to EE.

Significance Statement

Chondroitin sulfate proteoglycan (CSPG) is a candidate regulator of embryonic neurogenesis. Here, we specified the role of CSPG in adult neurogenesis in the mouse hippocampus. Digestion of CSPG in the dentate gyrus impaired granule cell production and cognitive memory. Enriched environment (EE) promoted the recovery of CSPG expression and granule cell production from the CSPG digestion. Additionally, adult neurogenesis was impaired in mice that lacked a key enzyme for CSPG synthesis (T1K0 mice). The capacity of EE to promote granule cell production and cognitive memory was impaired in T1KO mice. Altogether, these findings indicate that CSPG underlies adult hippocampal neurogenesis and suggest that increased synthesis of CSPG may mediate promotion of granule cell production in response to $\mathrm{EE}$.

Key words: chondroitin sulfate proteoglycan; hippocampus; neurogenesis; enriched environment

\section{Introduction}

Neural stem cells are present in both embryonic and adult brain of mammals, including humans (Gage, 2000). The production of granule cells from neural stem cells in the dentate gyrus continues throughout life and this phenomenon is termed as "adult hippocampal neurogenesis" (Altman and Das, 1967; Kaplan and Hinds, 1977; Cameron et al., 1993). To date, newborn granule cells are thought to play some role in regulation of higher-order brain functions (Opendak and Gould, 2015): cognitive memory (Contestabile et al., 2013), spatial memory (Shors et al., 2001;

neuronal functions" 26110714 to S.J.). We thank Machiko Endoh for secretarial assistance, Kana Maekawa for technical assistance, and Editage (https://www.editage.jp/) for English language editing.

The authors declare no competing financial interests. 
Dupret et al., 2007), mood regulation, and efficacy of antidepressants (Petrik et al., 2012).

Extracellular matrix (ECM) is considered to enrich and enhance the bioavailability of multiple endogenous factors (Kazanis and ffrench-Constant, 2011). Interestingly, ECM constitutes specialized microenvironments known as neurogenic niches, which support the self-renewal of neural stem cells and their differentiation into neurons and glial cells (Spradling et al., 2001; Bordey, 2006). Chondroitin sulfate proteoglycan (CSPG) is one of the major components of ECM, consisting of a core protein and glycosaminoglycan side chains. Several studies have suggested that CSPG may be involved in regulation of neural stem cells in the developing brain (Purushothaman et al., 2012). Particularly, CSPG interacts with a number of growth factors such as pleiotrophin and midkine and influences proliferation and self-renewal of neural stem cells (Deepa et al., 2002; Mizoguchi et al., 2003; Karumbaiah et al., 2015). Currently, there is fairly general agreement that CSPG is a candidate regulator of embryonic neurogenesis (Sirko et al., 2007). However, the potential role of CSPG in adult hippocampal neurogenesis is still not fully understood.

The expression of perineuronal net (PNN), which is the specialized reticular structure composed of CSPG and hyaluronan, is promoted in the developing visual cortex in response to visual experiences (Pizzorusso et al., 2002). The numbers of PNNs labeled by Wisteria floribunda agglutinin (WFA, a marker for CSPG) in the barrel cortex decrease following deprivation of sensory information from facial vibrissae (Nakamura et al., 2009). Although neural stem cells are not surrounded by PNNs, CSPG is highly expressed in neurogenic niches (Akita et al., 2008). Interestingly, adult hippocampal neurogenesis is also affected by various experiences that modulate neuronal activity. For example, granule cell production is increased by enriched environment (EE) (Kempermann and Gage, 1999) and decreased by physiological and psychological stresses (Czéh et al., 2002; Pham et al., 2003). Therefore, it can be hypothesized that CSPG may play some role in experience-dependent alterations in adult hippocampal neurogenesis.

The main goal of the present study was to specify the functional significance of CSPG in adult neurogenesis in the mouse hippocampus. Here, we showed that neural stem cells and neuronal progenitors in the dentate gyrus were partially covered by CSPG. Pharmacological depletion of CSPG in the dentate gyrus reduced the densities of neuronal progenitors and newborn granule cells and caused cognitive memory impairment. In addition, EE promoted the recovery of CSPG expression and the restoration of granule cell production from CSPG digestion. Moreover, the capacity of EE to promote granule cell production and improve cognitive memory was impaired in mice that lacked a key enzyme for CSPG synthesis. Altogether, these findings indicate that CSPG is involved in regulation of adult hippocampal neurogenesis and suggest that increased synthesis of CSPG may mediate promotion of granule cell production and improvement of cognitive memory in response to EE.

\section{Materials and Methods}

Animals. All procedures were approved by the Committee of Ethics on Animal Experiments of the Graduate School of Medical Sciences, Kyushu

Correspondence should be addressed to Dr. Shozo Jinno, Kyushu University, Department of Anatomy and Neuroscience, Graduate School of Medical Sciences, 3-1-1 Maidashi, Higashi-ku, Fukuoka 812-8582, Japan. E-mail: sjnno@med.kyushu-u.ac.jp.

DOI:10.1523/JNEUROSCI.0632-18.2018

Copyright $\odot 2018$ the authors $\quad 0270-6474 / 18 / 388497-18 \$ 15.00 / 0$
University. Mice were housed on a $12 \mathrm{~h}$ light/12 h dark cycle and fed ad libitum standard rodent chow (CE-2; CLEA Japan).

A total of 161 male C57BL/6J mice (8-12 weeks old, 20-25 g; CLEA Japan) were used in this study. We also used 22 male mice lacking the gene for chondroitin sulfate $\mathrm{N}$-acetylgalactosaminyltransferase 1 (CSGalNAcT1), a key enzyme for CSPG synthesis (T1KO mice; 8-12 weeks old, 20-25 g) and 21 male wild-type littermates (WT mice; 8-12 weeks old, $20-25 \mathrm{~g}$ ). T1KO mice, T1 heterozygotes, and WT littermates on the C57BL/6N background were bred, genotyped, and maintained as described previously (Watanabe et al., 2010).

Enriched housing. In an EE, mice were housed in a large plastic cage $(45 \times 30 \times 25 \mathrm{~cm})$ that contained tunnels, running wheels, and toys. In standard conditions, mice were housed in a standard plastic cage $(12 \times$ $20 \times 15 \mathrm{~cm})$ that contained no such items. Mice were housed either in standard conditions or in an EE for 2 weeks.

Forced swimming stress. Mice were forced to swim for $6 \mathrm{~min}$ in an acrylic cylinder $(20 \times 20 \times 25 \mathrm{~cm})$ containing $15 \mathrm{~cm}$ water at $25^{\circ} \mathrm{C}$ once daily for 2 weeks. After the swimming session, each animal was dried, warmed, and returned to its home cage.

Administration of enzymatic reagents. Three types of chondroitinases were used to analyze the potential role of CSPG: chondroitinase ABC (chABC, $30 \mathrm{U} / \mathrm{ml}, 0.25 \mu \mathrm{l} / \mathrm{site}$; Seikagaku), which digests both CSPG and dermatan sulfate proteoglycan (DSPG); chondroitinase AC (chAC, 30 $\mathrm{U} / \mathrm{ml}, 0.25 \mu \mathrm{l} /$ site; Seikagaku), which digests CSPG only; and chondroitinase B (chB, $30 \mathrm{U} / \mathrm{ml}, 0.25 \mu \mathrm{l} /$ site; Sigma-Aldrich), which digests DSPG only (Michelacci and Dietrich, 1975). As a control regent, we used penicillinase (P-ase, $30 \mathrm{U} / \mathrm{ml}, 0.25 \mu \mathrm{l} /$ site; Sigma-Aldrich).

Mice were anesthetized with intraperitoneal injection of sodium pentobarbital $(50 \mathrm{mg} / \mathrm{kg})$ and mounted onto a stereotaxic frame. Each reagent was applied using positive pressure with a glass micropipette (inside diameter, $20-30 \mu \mathrm{m}$ ). For immunohistochemistry (IHC) and Western blot, each regent was injected into four target sites of the dorsal dentate gyrus in the left hemisphere. For behavioral experiments, each reagent was injected into four target sites of the dorsal dentate gyrus in both hemispheres.

The coordinates of injection sites were as follows: (1) $1.84 \mathrm{~mm}$ anterior to the bregma, $1.0 \mathrm{~mm}$ lateral from the midline, and $1.90 \mathrm{~mm}$ below the pial surface; (2) $1.84 \mathrm{~mm}$ anterior to the bregma, $1.2 \mathrm{~mm}$ lateral from the midline, and $1.90 \mathrm{~mm}$ below the pial surface; (3) $2.18 \mathrm{~mm}$ anterior to the bregma, $1.2 \mathrm{~mm}$ lateral from the midline, and $1.90 \mathrm{~mm}$ below the pial surface; and (4) $2.18 \mathrm{~mm}$ anterior to the bregma, $1.5 \mathrm{~mm}$ lateral from the midline, and $1.90 \mathrm{~mm}$ below the pial surface.

Administration of bromodeoxyuridine ( $B r d U$ ). To identify proliferating cells, mice were administered single intraperitoneal injection of BrdU (50 $\mathrm{mg} / \mathrm{kg}$; Nacalai Tesque) 2 weeks after the intradentate injection of reagents as described above. BrdU is a thymidine analog that incorporates into DNA during S phase of the cell cycle (Taupin, 2007). Animals were killed $24 \mathrm{~h}$ after the BrdU injection.

To identify mature newborn granule cells, mice were administered intraperitoneal injection of $\mathrm{BrdU}$ ( $50 \mathrm{mg} / \mathrm{kg}$; Nacalai Tesque) once daily for 2 consecutive days. One week after the final BrdU injection, animals received intradentate injection of reagents as described above. Animals were killed 4 weeks after the final BrdU injection.

Perfusion fixation. For IHC, mice were deeply anesthetized with an overdose of sodium pentobarbital $(120 \mathrm{mg} / \mathrm{kg}$, i.p.) and then perfused transcardially with PBS, $\mathrm{pH} 7.4$, followed by a mixture of $4 \%$ paraformaldehyde and $0.05 \%$ glutaraldehyde in $0.1 \mathrm{~m}$ phosphate buffer, $\mathrm{pH}$ 7.4. Brains were left in situ for 2-3 h at room temperature and then removed from the skull. Harvested brains were cut coronally into $40-\mu \mathrm{m}$-thick sections on a vibrating microtome (VT1000S; Leica Microsystems). To avoid deformation of the sections, they were processed free-floating with extreme care.

Immunostaining procedure. For antigen retrieval of BrdU, caspase- 3 (Casp-3), and proliferating cell nuclear antigen (PCNA), sections were pretreated with $2 \mathrm{~N} \mathrm{HCl}$ for $30 \mathrm{~min}$ at room temperature. After washing with PBS, all sections were blocked with $1.0 \%$ BSA in PBS containing $0.3 \%$ Triton X-100 and $0.05 \%$ sodium azide for $3 \mathrm{~h}$ at $4^{\circ} \mathrm{C}$. After blocking, sections were incubated for $5 \mathrm{~d}$ at $4^{\circ} \mathrm{C}$ with a mixture of primary antibodies raised in different species and a plant lectin: rat monoclonal 
anti-BrdU antibody (1:1000; Novus Biologicals; RRID:AB_341913), rabbit polyclonal anti-brain lipid-binding protein (BLBP) antibody (1:2000; Abcam; RRID:AB_10711451), rabbit polyclonal anti-calretinin (CR) antibody (1:10000; Frontier Institute; RRID:AB_2571666), rabbit monoclonal anti-Casp-3 (cleaved) antibody (1:2000; Cell Signaling Technology; RRID:AB_2341188), guinea pig polyclonal anti-doublecortin (DCX) antibody (1:10000; Millipore; RRID:AB_2230227), mouse monoclonal anti-glial fibrillary acidic protein (GFAP) antibody (1:10000; Sigma-Aldrich; RRID:AB_477010), rabbit polyclonal anti-ionized calcium binding adaptor molecule 1 (Ibal) antibody (1:10000; Wako; RRID:AB_2665520), chicken polyclonal anti-neuronal nuclei (NeuN) antibody (1:2000; Synaptic Systems; RRID:AB_2571734), goat polyclonal anti-sex determining region Y-box 2 (Sox2) antibody (1:2000; Santa Cruz Biotechnology; RRID:AB_661259), rabbit polyclonal antiparvalbumin (PV) antibody (1:10000; Swant; RRID:AB_2315235), mouse monoclonal anti-PCNA antibody (1:2000; Millipore; RRID: AB_95029), and biotinylated-WFA lectin (1:5000; Vector Laboratories; RRID:AB_2336873).

After washing with PBS, sections were incubated with a mixture of appropriate fluorescent or biotin-conjugated secondary antibodies: aminomethylcoumarin-conjugated donkey anti-rabbit IgG antibody ( 1 : 500; Jackson ImmunoResearch Laboratories), fluorescein isothiocyanate (FITC)-conjugated donkey anti-rabbit IgG antibody (1:500; Jackson ImmunoResearch Laboratories), FITC-conjugated donkey anti-guinea pig IgG antibody (1:500; Jackson ImmunoResearch Laboratories), cyanine 3 (Cy3)-conjugated donkey anti-goat IgG antibody (1:250; Jackson ImmunoResearch Laboratories), Alexa Fluor 647-conjugated donkey antimouse IgG antibody (1:250; Jackson ImmunoResearch Laboratories), biotin-conjugated donkey anti-chicken IgG antibody (1:500; Jackson ImmunoResearch Laboratories) for $12 \mathrm{~h}$ at $4^{\circ} \mathrm{C}$. Sections were then incubated with CF405-conjugated streptavidin (1:500; Biotium). Some sections were also counterstained with 4',6-diamidino-2-phenylindole (DAPI; $1 \mu \mathrm{g} / \mathrm{ml}$; Nacalai Tesque) for $30 \mathrm{~min}$. After washing with PBS, sections were mounted in Vectashield (Vector Laboratories).

Counting procedure according to the optical disector. One stack of optical sections containing the dentate gyrus was captured from each immunostained section using an optical sectioning microscope (Apotome.2; Carl Zeiss) equipped with a dry objective lens $[\times 20$, numerical aperture (NA) 0.8]. A two-cell-thick zone $(40 \mu \mathrm{m})$ between the border of the granule cell layer and hilus was defined as the subgranular zone and adult neurogenesis-related cells distributed in this narrow band were counted according to the optical disector procedure (West et al., 1991). The area of the granule cell layer was estimated according to the point-counting method (Gundersen et al., 1999) using the image analysis software package ImageJ 1.46 (RRID:SCR_003070). The numerical densities (NDs) were calculated as follows:

$$
\mathrm{ND}=\Sigma Q^{-} /(h \times a(g l) / \mathrm{SV})
$$

where $\Sigma Q^{-}$is the number of disector-counted cells in the subgranular zone, $h$ is the optical disector height, $a(g l)$ is the area of the granule cell layer, and SV is the volumetric shrinkage factor. Here, we used the average value of SV for Vectashield-mounted preparations (0.65) (Jinno et al., 1998). The numbers of cells counted by the optical disector analyses are summarized in Table 1.

Optical disector analysis of the cells stained for Sox2, DCX, CR, and S100ß. In this experiment, four types of adult neurogenesis-related cells were defined as follows: Sox $2^{+} / \mathrm{DCX}^{-} / \mathrm{CR}^{-} / \mathrm{S} 100 \beta^{-}$neural stem cells, Sox ${ }^{-} /$ $\mathrm{DCX}^{+} / \mathrm{CR}^{-} / \mathrm{S} 100 \beta^{-}$neuronal progenitors, Sox $2^{-} / \mathrm{DCX}^{+} / \mathrm{CR}^{+} / \mathrm{S} 100 \beta^{-}$ newborn granule cells, and Sox $2^{+} / \mathrm{DCX}^{-} / \mathrm{CR}^{-} / \mathrm{S} 100 \beta^{+}$astrocytes.

To examine the effects of CSPG digestion on adult neurogenesis, a total of 16 mice were divided into four groups that were treated with different reagents: P-ase, $n=4$ mice; chABC, $n=4$ mice; chAC, $n=4$ mice; chB, $n=4$ mice. These animals were also used for the reconstruction of newborn granule cells.

To examine the effects of EE or stress on adult neurogenesis, a total of 24 mice were divided into four groups that were treated with different reagents: control, $n=8$ mice; EE, $n=8$ mice; Stress, $n=8$ mice. These animals were also used for the fluorescent intensity analysis of WFA.
Table 1. Numbers of counted cells by the optical disector analysis

\begin{tabular}{|c|c|c|c|c|}
\hline Figure $21-L$ & $\begin{array}{l}\text { Neural stem } \\
\text { cells }\end{array}$ & $\begin{array}{l}\text { Neuronal } \\
\text { progenitors }\end{array}$ & $\begin{array}{l}\text { Newborn } \\
\text { granule cells }\end{array}$ & Astrocytes \\
\hline P-ase & 1026 & 993 & 1384 & 222 \\
\hline $\operatorname{ch} A B C$ & 871 & 391 & 386 & 184 \\
\hline chAC & 851 & 487 & 384 & 174 \\
\hline $\operatorname{chB}$ & 902 & 836 & 1126 & 184 \\
\hline Figure $2 R-T$ & $\begin{array}{l}\text { Total BrdU } \\
\text { cells }\end{array}$ & $\begin{array}{l}\text { BrdU }{ }^{+} \text {neural } \\
\text { stem cells }\end{array}$ & $\begin{array}{l}\text { BrdU }^{+} \text {neuronal } \\
\text { progenitors }\end{array}$ & \\
\hline P-ase & 264 & 53 & 204 & \\
\hline chABC & 197 & 59 & 131 & \\
\hline chAC & 183 & 62 & 112 & \\
\hline $\operatorname{chB}$ & 273 & 68 & 198 & \\
\hline Figure $3 L, 0$ & $\begin{array}{l}\mathrm{BrdU}^{+} \text {mature } \\
\text { granule cells }\end{array}$ & $\begin{array}{l}\text { Casp-3 }{ }^{+} \text {apoptotic } \\
\text { cells }\end{array}$ & & \\
\hline P-ase & 267 & 46 & & \\
\hline chABC & 184 & 41 & & \\
\hline $\operatorname{chAC}$ & 204 & 38 & & \\
\hline $\operatorname{chB}$ & 268 & 40 & & \\
\hline Figure $6 L-0$ & $\begin{array}{l}\text { Neural stem } \\
\text { cells }\end{array}$ & $\begin{array}{l}\text { Neuronal } \\
\text { progenitors }\end{array}$ & $\begin{array}{l}\text { Newborn } \\
\text { granule cells }\end{array}$ & Astrocytes \\
\hline P-ase & 1997 & 1745 & 2329 & 436 \\
\hline $\mathrm{EE}$ & 2159 & 2106 & 3588 & 399 \\
\hline Stress & 1458 & 1398 & 850 & 406 \\
\hline Figure $7 /-L$ & $\begin{array}{l}\text { Neural stem } \\
\text { cells }\end{array}$ & $\begin{array}{l}\text { Neuronal } \\
\text { progenitors }\end{array}$ & $\begin{array}{l}\text { Newborn } \\
\text { granule cells }\end{array}$ & Astrocytes \\
\hline P-ase (EE) & 952 & 958 & 1638 & 180 \\
\hline chABC (EE) & 839 & 716 & 597 & 168 \\
\hline $\operatorname{chAC}(\mathrm{EE})$ & 823 & 737 & 623 & 175 \\
\hline $\mathrm{chB}(\mathrm{EE})$ & 994 & 972 & 1688 & 174 \\
\hline Figure 8J-M & $\begin{array}{l}\text { Neural stem } \\
\text { cells }\end{array}$ & $\begin{array}{l}\text { Neuronal } \\
\text { progenitors }\end{array}$ & $\begin{array}{l}\text { Newborn } \\
\text { granule cells }\end{array}$ & Astrocytes \\
\hline WT (STD) & 808 & 787 & 951 & 178 \\
\hline T1K0 (STD) & 798 & 697 & 666 & 164 \\
\hline WT (EE) & 914 & 963 & 1739 & 161 \\
\hline T1KO (EE) & 742 & 742 & 695 & 151 \\
\hline
\end{tabular}

To examine the effects of EE on the recovery of adult neurogenesis from CSPG digestion, a total of 16 mice housed under EE were divided into four groups that were treated with different reagents: $\mathrm{P}$-ase $(\mathrm{EE}), n=4$ mice; chABC (EE), $n=4$ mice; chAC (EE), $n=4$ mice; $\operatorname{chB}$ (EE), $n=4$ mice.

To analyze the effects of genetic deletion of CSGalNAcT1 and EE on adult neurogenesis, a total of 16 mice were divided into four groups: untreated WT mice housed in standard conditions, WT (STD), $n=4$ mice; T1KO mice housed in standard conditions, T1KO (STD), $n=4$ mice; WT mice housed in an EE, WT (EE), $n=4$ mice; T1KO mice housed in an EE, T1KO (EE), $n=4$ mice. These animals were also used for the fluorescent intensity analysis of WFA and volume rendering.

From each animal, three sections were selected and processed for immunostaining of Sox 2, DCX, CR, and S100 $\beta$. The image acquisition conditions, cell-counting procedures, and calculation method of the NDs were performed as described above.

Optical disector analysis of the cells stained for Sox2, DCX, BrdU, and $S 100 \beta$. In this experiment, two types of proliferating cells were defined as follows: Sox $2^{+} / \mathrm{DCX}^{-} / \mathrm{BrdU}^{+} / \mathrm{S} 100 \beta^{-}$neural stem cells and Sox $2^{-} /$ $\mathrm{DCX}^{+} / \mathrm{BrdU}^{+} / \mathrm{S} 100 \beta^{-}$neuronal progenitors. A total of 16 mice were divided into four groups that were treated with different reagents: $\mathrm{P}$-ase, $n=4$ mice; chABC, $n=4$ mice; $\operatorname{chAC}, n=4$ mice; chB, $n=4$ mice.

From each animal, three sections were processed for immunostaining of Sox2, DCX, BrdU, and S100 $\beta$. The image acquisition conditions, cellcounting procedures, and calculation methods for the NDs were performed as described above.

Optical disector analysis of the cells stained for DCX, CR, BrdU, and $\mathrm{NeuN}$. In this experiment, $\mathrm{DCX}^{-} / \mathrm{CR}^{-} / \mathrm{BrdU}^{+} / \mathrm{NeuN}^{+}$cells were defined as mature newborn granule cells. A total of 16 mice were divided 
into four groups that were treated with different reagents: $\mathrm{P}$-ase, $n=4$ mice; chABC, $n=4$ mice; chAC, $n=4$ mice; chB, $n=4$ mice. These animals were also used for the optical disector analysis of the cells stained for Casp-3 and DAPI.

From each animal, three sections were processed for immunostaining of DCX, BrdU, CR, and NeuN. The image acquisition conditions, cellcounting procedures, and calculation method for the NDs were performed as described above.

Optical disector analysis of the cells stained for Casp-3 and DAPI. In this experiment, Casp- $3^{+} / \mathrm{DAPI}^{+}$cells were defined as apoptotic cells. A total of 16 mice were divided into four groups that were treated with different reagents: P-ase, $n=4$ mice; chABC, $n=4$ mice; chAC, $n=4$ mice; $\operatorname{chB}, n=4$ mice.

From each animal, three sections were processed for immunostaining of casp-3. The image acquisition conditions, cell-counting procedures, and calculation method for the NDs were performed as described above.

Line profile analysis. To analyze the contact between the WFA ${ }^{+} \mathrm{CSPG}$ and $\mathrm{PV}^{+}, \mathrm{BLBP}^{+}$, or $\mathrm{DCX}^{+}$cells, optical sections were obtained with an optical sectioning microscope (Apotome.2; Carl Zeiss) using an oilimmersion objective lens ( $\times 63$, NA 1.40). The pixel intensities within 15 $\mu \mathrm{m}$ of the lines were measured using ImageJ 1.46 .

Fluorescence intensity analysis of WFA. To analyze the effects of EE and stress on CSPG expression in the dentate gyrus, a total of 24 mice were divided into three groups that were housed under different conditions: control, $n=8$ mice; EE, $n=8$ mice; stress, $n=8$ mice. To analyze the recovery of CSPG expression from pharmacological digestion by housing in an EE, a total of 16 mice were divided into four groups that were treated with different reagents: $\mathrm{P}$-ase (EE), $n=4$ mice; chABC (EE), $n=$ 4 mice; $\operatorname{chAC}$ (EE), $n=4$ mice; $\operatorname{chB}(\mathrm{EE}), n=4$ mice. For comparison, we analyzed mice housed in standard conditions after injection of chABC: chABC (STD), $n=4$ mice. To analyze the alterations in $\mathrm{WFA}^{+} \mathrm{CSPG}^{-}$ expression by genetic deletion of CSGalNAcT1, a total 16 mice were divided into four groups according to the genetic backgrounds and housing conditions: WT (STD), $n=4$ mice; T1KO (STD), $n=4$ mice; WT (EE), $n=4$ mice; T1KO (EE), $n=4$ mice.

Three sections per animal were processed for staining of WFA. We used long-focal-depth images obtained from a wide-field fluorescence microscope (Axio Scope.A1; Carl Zeiss) equipped with a dry objective lens ( $\times 5$, NA 0.15) (Yamada et al., 2015). Before capturing images, we carefully set the exposure time, gain, and offset to ensure a high signal while also avoiding saturation. The same capture conditions were used for all sections. Eight-bit black and white images containing the whole area of the hippocampus were captured using a digital camera (AxioCam MRm; Carl Zeiss). The gray levels for $\mathrm{WFA}^{+} \mathrm{CSPG}^{+}$in the dentate gyrus were measured using ImageJ 1.46.

Reconstruction of newborn granule cells. A total of 16 mice were divided into four groups that were treated with different reagents: $\mathrm{P}$-ase, $n=4$ mice; chABC, $n=4$ mice; chAC, $n=4$ mice; chB, $n=4$ mice. Three sections per animal were selected and processed for immunostaining of DCX and CR. One stack of optical sections containing the dentate gyrus was captured using an optical sectioning microscope (Apotome.2; Carl Zeiss) equipped with a dry objective lens $(\times 40$, NA 0.75$)$. Cell bodies and processes of $\mathrm{DCX}^{+}$cells were traced using the Neurolucida V9 tracing and reconstruction software (MBF Bioscience). 3D datasets were analyzed quantitatively using Neurolucida Explorer (MBF Bioscience). The following morphometric parameters were obtained: (1) branch number: the total number of dendritic branches; (2) total dendritic length: the total length of all branched structures of dendrites; (3) length of secondorder dendrites; (4) length of third-order dendrites; and (5) number of intersections: the number of intersections made by $\mathrm{DCX}^{+}$dendrites with concentric circles of increasing distance from the cell body (Sholl analysis) (Sholl, 1953).

Volume rendering. A total of 12 mice were divided into four groups according to the genetic backgrounds and housing conditions: WT (STD), $n=3$ mice; T1KO (EE), $n=3$ mice; WT (EE), $n=3$ mice; T1 KO (EE), $n=3$ mice. For comparison, we analyzed mice that received intradentate injection of chABC and then were housed in standard conditions: chABC (STD), $n=3$ mice. All animals were also used in the optical disector analysis of the cells stained for Sox2, DCX, CR, and S100 $\beta$.
3D volume-rendering tool integrated in Fiji, a "batteries-included" version of ImageJ (Schindelin et al., 2012), was used in this analysis. Three sections per animal were processed for staining of WFA, PV, BLBP, and DCX. One stack of optical sections containing the dentate gyrus was captured using an optical sectioning microscope (Apotome.2; Carl Zeiss) equipped with an oil-immersion objective lens $(\times 63$, NA 1.40). Images for each channel (cyan, WFA; green, PV; yellow, BLBP, magenta, DCX) were processed separately to optimize the detection of $\mathrm{WFA}^{+} \mathrm{CSPG}$, $\mathrm{PV}^{+}, \mathrm{BLBP}^{+}$, or $\mathrm{DCX}^{+}$cells. Contrast for the cyan channel was corrected using the "enhance contrast" function ( saturated pixels $=0.2 \%$, normalized, all slices processed). Background was reduced using the "subtract background" function (rolling ball radius $=2$ pixels). Contrast for the green channel was corrected using the "enhance contrast" function (saturated pixels $=0.1 \%$, normalized, all slices processed). Background noise was reduced with the "subtract background" function (rolling ball radius $=30$ pixels). Contrast for the yellow channel was corrected with the "enhance contrast" function ( saturated pixels $=0.1 \%$, normalized, all slices processed). Background noise was reduced with the "subtract background" function (rolling ball radius $=40$ pixels). Contrast for the magenta channel was corrected using the "enhance contrast" function (saturated pixels $=0.1 \%$, normalized, all slices processed). Background noise was reduced with the "subtract background" function (rolling ball radius $=40$ pixels). All images were then automatically thresholded for segmentation by the "make binary" function ("auto threshold," "Otsu" method). The images were filtered through the 3D median filter (radius $=2$ pixels in every dimension). Finally, the cyan channel was merged with each of the green, yellow, and magenta channels and rendered with the plugin 3D Viewer (displayed as volume).

To estimate contact between $\mathrm{WFA}^{+} \mathrm{CSPG}$ and $\mathrm{PV}^{+}, \mathrm{BLBP}^{+}$, or $\mathrm{DCX}^{+}$cells, we defined the granule cell layer with the 3D region of interest (ROI) tool. The colocalized voxels (i.e., voxels double positive for WFA and each of PV, BLBP, and DCX) were obtained by the image calculator (operation "multiply"). The voxel numbers were then measured using the voxel counter. Contact between WFA ${ }^{+}$CSPG and each of the $\mathrm{PV}^{+}, \mathrm{BLBP}^{+}$, and $\mathrm{DCX}^{+}$cells was estimated with the following formula:

$$
\text { Contact ratio }(\%)=\Sigma \operatorname{Cov} / \Sigma T o v \times 100
$$

where $\Sigma$ Cov represents the number of double-positive voxels and $\Sigma$ Tov represents the total voxel number for $\mathrm{PV}^{+}, \mathrm{BLBP}^{+}$, and $\mathrm{DCX}^{+}$cells.

Western blot analysis. A total of 24 mice were divided into four groups that were treated with different reagents: $\mathrm{P}$-ase, $n=6$ mice; chABC, $n=$ 6 mice; chAC, $n=6$ mice; chB, $n=6$ mice. After administration of an overdose of sodium pentobarbital (120 mg/kg, i.p.), deeply anesthetized animals were transcardially perfused with ice-cold PBS. Harvested brains were cut coronally into 250 - $\mu \mathrm{m}$-thick sections in a bath of ice-cold PBS using a vibrating microtome (VT1000S; Leica Microsystems). The dorsal dentate gyrus was dissected from the brain section by hand using a razor blade. Tissues were homogenized in PBS by pipetting. For Western blotting of $\beta$-catenin, the nuclear fraction was extracted with NE-PER Nuclear and Cytoplasmic Extraction Reagents (Thermo Fisher Scientific) according to the manufacturer's protocol. Protein concentrations were determined using a Rapid Protein Quantification Kit (Dojindo) and subjected to SDS-PAGE (ATTO). The Western blot was repeated twice and a representative result is shown in Figure 4.

Transferred PVDF membranes were blocked with $5.0 \%$ skim milk in PBS-T (PBS containing $0.1 \%$ Tween 20) for $30 \mathrm{~min}$ at room temperature and incubated with goat polyclonal anti-Wnt-3 antibody (1:2000; Santa Cruz Biotechnology; RRID:AB_2215293) or mouse monoclonal anti- $\beta$ catenin antibody (1:2000; BD Bioscience; RRID:AB_397554) overnight at $4^{\circ} \mathrm{C}$. After washing with PBS-T, membranes were incubated with HRPconjugated goat anti-mouse IgG antibody (1:5000; Jackson ImmunoResearch Laboratories) for $3 \mathrm{~h}$ at $20^{\circ} \mathrm{C}$. After washing with PBS-T, the bound antibodies were detected with Immobilon Western Chemiluminescent HRP Substrate (Millipore) and images were acquired using a luminoimage analyzer (ImageQuant LAS 4000mini; GE Healthcare). Membranes were subsequently stripped with Western blot stripping buffer (Thermo Fisher Scientific) and then reblotted with mouse monoclonal antibody against the housekeeping gene $\beta$-actin (1:20000; Sigma- 
Aldrich; RRID:AB_476692) or TATA-binding protein (TBP, 1:20000; Abcam; RRID:AB_447457). To measure band intensities, equal-sized boxes were drawn around the bands, and the mean pixel values were measured using ImageJ 1.46.

High-performance liquid chromatography. For high-performance liquid chromatography (HPLC), a total of 13 mice were divided into three groups that were housed in different conditions: control, $n=5$ mice; EE, $n=4$ mice; stress, $n=4$ mice. After administration of an overdose of sodium pentobarbital (120 mg/kg, i.p.), deeply anesthetized animals were transcardially perfused with PBS. Harvested brains were cut coronally into 250- $\mu \mathrm{m}$-thick sections in a bath of ice-cold PBS using a vibrating microtome (VT1000S; Leica Microsystems). Brain slices were cut by hand with a razor blade and the dorsal dentate gyrus was dissected and homogenized in cold acetone. The homogenate was dried and exhaustively digested with actinase $\mathrm{E}$ (Kaken Pharma) at $60^{\circ} \mathrm{C}$ for $24 \mathrm{~h}$. The digest was treated with $5 \%$ trichloroacetic acid $(\mathrm{w} / \mathrm{v})$ and the acid-soluble fraction was extracted with diethyl ether. The aqueous phase was neutralized and subjected to gel filtration on a PD-10 column (GE Healthcare). The flow-through fractions were collected, evaporated until dry, and then dissolved in water. An aliquot of the sample was digested using chondroitinase $\mathrm{ABC}$ (Seikagaku) at $37^{\circ} \mathrm{C}$ for $2 \mathrm{~h}$. The digests were derivatized with a fluorophore, 2-aminobenzamide and then analyzed by anion-exchange HPLC (SLC-10A; Shimadzu) on a PA-03 column (YMC). Identification and quantification of the resulting disaccharides were achieved by comparison with chondroitin sulfate-derived authentic unsaturated disaccharides.

Open-field test (OFT). To measure the effects of CSPG digestion on locomotor activity and anxiety-related behavior, mice were evaluated by the OFT. A total of 49 mice housed in standard conditions were divided into four groups that were treated with different reagents: $\mathrm{P}$-ase, $n=12$ mice; chABC, $n=12$ mice; chAC, $n=12$ mice; chB, $n=13$ mice. Mice were placed in a square open field $(50 \times 50 \times 50 \mathrm{~cm}$; Muromachi Kikai) for a period of $10 \mathrm{~min}$ and allowed to move freely in the field. The center area size was designated as $30 \times 30 \mathrm{~cm}^{2}$. The distance traveled and the time spent in the center area and the outer zone were automatically measured by a computer-assisted data acquisition system, ANY-maze (Stoelting; RRID:SCR_014289).

Novel object recognition test (NORT). The alterations in cognitive memory were evaluated by the NORT. On the next day of OFT, the same animals were analyzed by NORT to examine the effects of CSPG digestion. The results of chABC-treated mice were also used to calculate the effects of $\mathrm{EE}$ in the following analysis. To evaluate the effects of genetic deletion of CSGalNACT1, a total of 27 mice housed in standard conditions were analyzed: WT (STD), $n=13$ mice; T1KO (STD), $n=14$ mice. The animals were then housed in an EE and analyzed by NORT: WT (EE), $n=13$ mice; T1 KO (EE), $n=14$ mice. For comparison, chABCtreated mice housed in an EE were analyzed: $\operatorname{chABC}(\mathrm{EE}), n=12$ mice.

The test was conducted in accordance with the previously reported protocol (Leger et al., 2013). Briefly, the task was performed in a square open field $(50 \times 50 \times 50 \mathrm{~cm}$; Muromachi Kikai). During the familiarization session, each mouse was allowed to individually explore two objects for $10 \mathrm{~min}$ and the time spent exploring each object was recorded. Thereafter, the mouse was returned to the home cage. Six hours later, the mouse was placed into the same open field in which one of the familiar objects had been replaced with a novel object. Object exploration behavior was defined as the mouse being within $2 \mathrm{~cm}$ of an object, directing its nose at the object, and being involved in active exploration such as sniffing. The exploration time was automatically measured by a computerassisted data acquisition system, ANY-maze (Stoelting).

Statistical analysis and preparation of illustrations. All numerical data were pooled for each animal. The scientific graphing and data analysis software Origin 8.5 (OriginLab; RRID:SCR_014212) was used to test the statistical difference between two groups by Welch's $t$ test. The statistical analysis and data mining software SPSS Version 22 (RRID:SCR_002865) was used to test the statistical difference among multiple groups by oneway ANOVA with post hoc Tukey's honestly significant difference (HSD) test. Data are shown as mean \pm SD. Differences were considered significant at $p<0.05$.

To prepare illustrations, selected images were processed using Adobe Photoshop CS5 (RRID:SCR_014199). Only brightness and contrast were adjusted for the whole frame and no part of a frame was enhanced or modified in any way.

\section{Results}

Neural stem cells and neuronal progenitors in the adult hippocampus are partially covered by CSPG

We examined the localizations of CSPG around cells expressing PV, BLBP (a marker for radial glia-like neural stem cells) (Kriegstein and Alvarez-Buylla, 2009), and DCX (a marker for neuronal progenitors and newborn granule cells) (Brown et al., 2003) in the dentate gyrus of the adult mouse hippocampus. PV-positive $\left(\mathrm{PV}^{+}\right)$cells were clearly covered by WFA ${ }^{+}$CSPG, which exhibited the typical morphology of PNNs, as reported previously (Brückner et al., 1994) (Fig. 1A-C). In agreement with our recent work (Yamada et al., 2015), no PV-lacking interneurons were covered by WFA ${ }^{+}$CSPG in the hippocampus. $\mathrm{BLBP}^{+}$cells with radial processes, which were presumed to be neural stem cells, were partially covered by WFA ${ }^{+}$CSPG (Fig. $\left.1 D-F\right)$. DCX ${ }^{+}$cells with long, dendritic-like processes, which were presumed to be neuronal progenitors or newborn granule cells, were also partially covered by $\mathrm{WFA}^{+}$CSPG (Fig. $1 G-I$ ). In general, the covering of $\mathrm{BLBP}^{+}$cells and $\mathrm{DCX}^{+}$cells by $\mathrm{WFA}^{+}$CSPG was diffuse and did not exhibit the typical morphology of $\mathrm{WFA}^{+}$PNNs around $\mathrm{PV}^{+}$neurons.

We then examined the covering of $\mathrm{WFA}^{+} \mathrm{CSPG}$ around proliferating cells: $\mathrm{BLBP}^{+} / \mathrm{PCNA}^{+}$cells $\left(\right.$Fig. $1 J, K$ ) and $\mathrm{DCX}^{+} /$ PCNA $^{+}$cells (Fig. $1 L, M$ ). These cells lacked long processes and their somata were only weakly covered by WFA ${ }^{+}$CSPG.

\section{Reduction in neuronal progenitors and newborn granule cells following CSPG digestion}

The general distributions of CSPG in the hippocampus were tested after the injection of $\mathrm{P}$-ase or chABC into the dentate gyrus (Fig. 2A,B). Compared with $\mathrm{P}$-ase-treated mice, the staining for WFA in the dentate gyrus was evidently weakened in chABCtreated mice. In addition, digestion of CSPG somewhat spread into the $\mathrm{CA} 1$ and $\mathrm{CA} 3$ regions by the intradentate chABC injection and $\mathrm{WFA}^{+}$CSPG was present only around a few somata in these regions of chABC-treated mice.

We then examined the glial reactions at the injection site (Fig. $2 C, D)$. The patterns of distributions of $\mathrm{Ibal}^{+}$microglia and $\mathrm{GFAP}^{+}$astrocytes in mice treated with chABC were similar to those in mice treated with $\mathrm{P}$-ase. No morphological abnormalities were apparent in these glial cells.

Four molecular markers were used to analyze the effects of CSPG digestion on adult hippocampal neurogenesis: Sox2 (a marker for neural stem cells and astrocytes), DCX, CR (a marker for postmitotic immature granule cells), and $S 100 \beta$ (a marker for astrocytes). Here, we defined four types of adult neurogenesisrelated cells (Gage, 2000; Brandt et al., 2003; Yamada et al., 2016): Sox $2^{+} / \mathrm{DCX}^{-} / \mathrm{CR}^{-} / \mathrm{S} 100 \beta^{-}$neural stem cells (multipotent, theoretically unlimited self-renewing), Sox $2^{-} / \mathrm{DCX}^{+} / \mathrm{CR}^{-} / \mathrm{S} 100 \beta^{-}$ neuronal progenitors (restricted lineage potential, theoretically limited self-renewing) (Seaberg and van der Kooy, 2003), Sox ${ }^{-} /$ $\mathrm{DCX}^{+} / \mathrm{CR}^{+} / \mathrm{S} 100 \beta^{-}$newborn granule cells (postmitotic, immature), and Sox $2^{+} / \mathrm{DCX}^{-} / \mathrm{CR}^{-} / \mathrm{S} 100 \beta^{+}$astrocytes.

Quadruple-labeled fluorescence images of the dentate gyrus were obtained for optical disector analysis after treatment with P-ase (Fig. 2E), chABC (Fig. 2F), chAC (Fig. 2G), or chB (Fig. $2 H$ ). The NDs of neural stem cells (Fig. 2I) and astrocytes (Fig. $2 L$ ) were comparable among the four groups. By contrast, the 


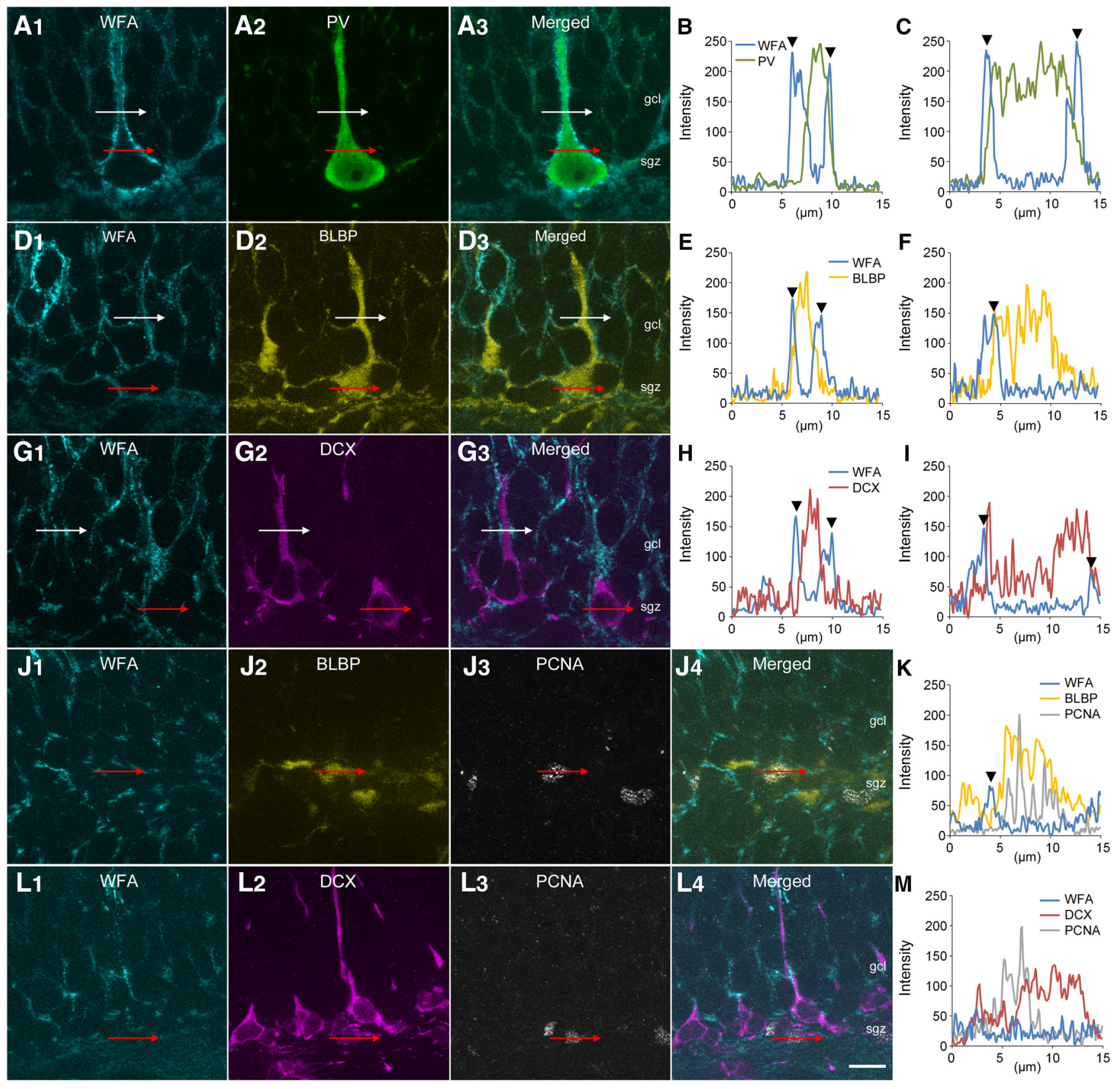

Figure 1. Localizations of CSPG in the dentate gyrus of the adult mouse hippocampus. $\boldsymbol{A}-\boldsymbol{C}$, Fluorescence images of WFA ${ }^{+}$CSPG (cyan, $\boldsymbol{A}$ ), PV (green, $\boldsymbol{A 2}$ ), and merged (A3). White lines represent the path crossing the process and its line profile is shown in $\boldsymbol{B}$. Red lines represent the path crossing the soma and its line profile is shown in $\boldsymbol{C}$. Arrowheads represent the peak intensities of WFA. D-F, Fluorescence images of WFA ${ }^{+}$CSPG (cyan, D1), BLBP (yellow, D2), and merged (D3). White lines represent the path crossing the process and its line profile is shown in $\boldsymbol{E}$. Red lines represent the path crossing the soma and its line profile is shown in $\boldsymbol{F}$. Arrowheads represent the peak intensities of WFA. G-I, Fluorescence images of WFA ${ }^{+}$CSPG (cyan, G1), DCX (magenta, G2), and merged (G3). White lines represent the path crossing the process and its line profile is shown in $\boldsymbol{H}$. Red lines represent the path crossing the soma and its line profile is shown in $\boldsymbol{I}$. Arrowheads represent the peak intensities of WFA. $J, K$, Fluorescence images of WFA ${ }^{+}$CSPG (cyan, J1), BLBP (yellow, $J 2$ ), PCNA (gray, J3), and merged (J4). Red lines represent the path crossing the soma and its line profile is shown in $\boldsymbol{K}$. An arrowhead represents the peak intensity of WFA. $L, M$, Fluorescence images of WFA ${ }^{+}$CSPG (cyan, $\mathbf{L} \mathbf{1}$ ), DCX (magenta, L2), PCNA (gray, L3), and merged (L4). Red lines represent the path crossing the soma and its line profile is shown in $\boldsymbol{M}$. Scale bar in $\mathbf{L} \mathbf{4}=10 \mu \mathrm{m}$ and applies to $A, \boldsymbol{D}, \mathbf{G}$ $J$, and $\boldsymbol{L}$.

NDs of neuronal progenitors (Fig. $2 J$ ) and newborn granule cells (Fig. $2 K$ ) were lower in mice treated with chABC or chAC than in mice treated with $\mathrm{P}$-ase.

\section{Reduction in the proliferation of neuronal progenitors following CSPG digestion}

The effects of CSPG digestion on cell proliferation of neural stem cells and neuronal progenitors were estimated by the immunostaining for Sox2, DCX, BrdU, and S100 $\beta$ (Fig. $2 M-P$ ). Two weeks after the intradentate injection of enzymatic reagents, animals received intraperitoneal injection of BrdU and were killed 24 h later (Fig. 2Q). The NDs of total $\mathrm{BrdU}^{+}$proliferating cells were lower in mice treated with chABC or chAC than in mice treated with $\mathrm{P}$-ase or chB (Fig. $2 R$ ). The $\mathrm{NDs}$ of $\mathrm{BrdU}^{+}$proliferating neural stem cells were comparable among the four groups (Fig. 2S). By contrast, the NDs of $\mathrm{BrdU}^{+}$proliferating neuronal progenitors were lower in mice treated with chABC or chAC than in mice treated with $\mathrm{P}$-ase or chB (Fig. 2T). 


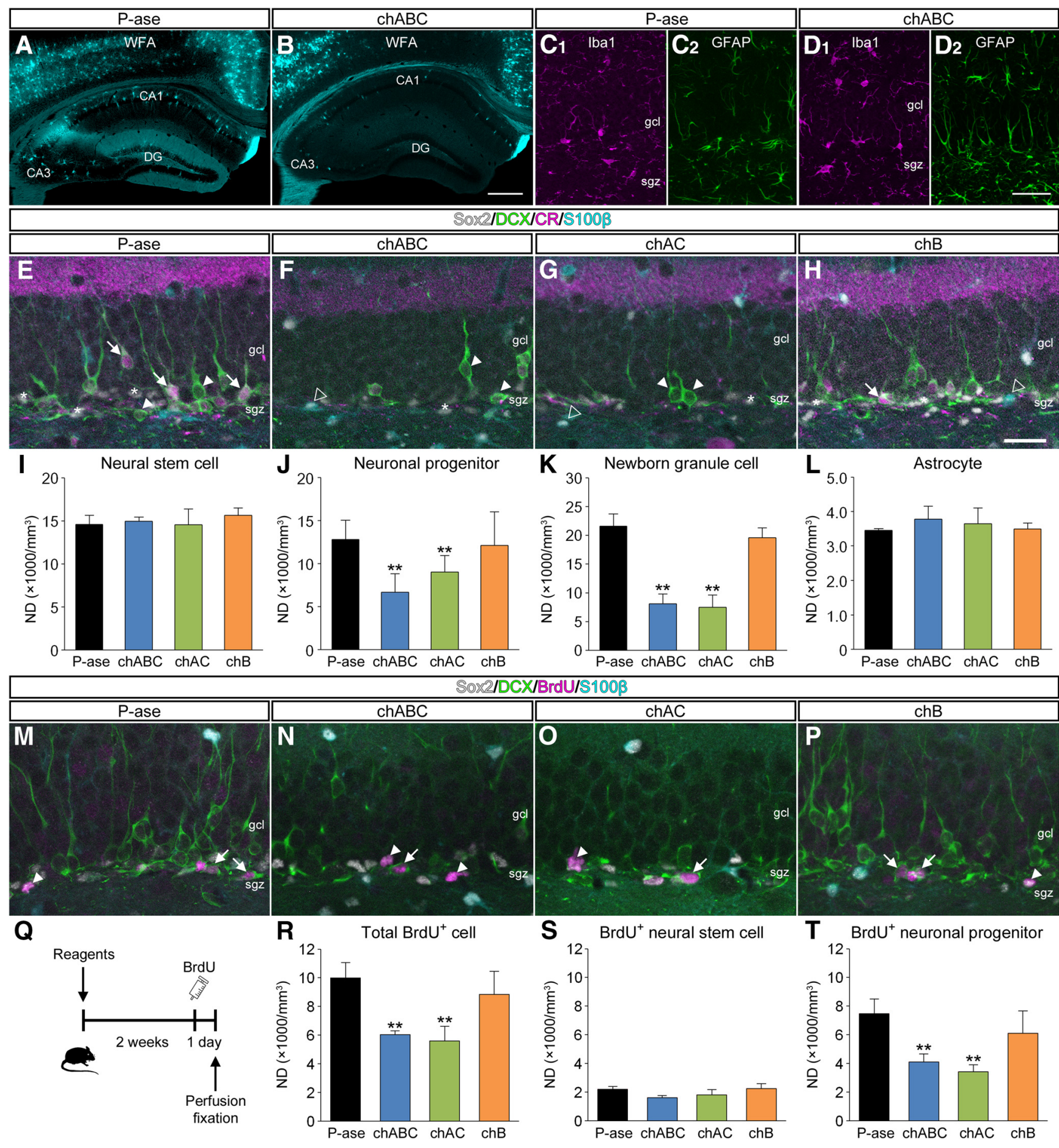

Figure 2. Impairment of adult hippocampal neurogenesis following CSPG digestion. $A, B$, Fluorescence images of WFA ${ }^{+}$CSPG (cyan) in the hippocampus of mice that received intradentate injection of P-ase $(\boldsymbol{A})$ or chABC $(\boldsymbol{B})$. C, D, Fluorescence images of Iba1 (magenta, $\mathbf{C 1}, \mathbf{D}$ ) and GFAP (green, $\boldsymbol{C 2}, \mathbf{D 2}$ ) at the injection site. $\boldsymbol{E}$ - $\boldsymbol{H}$, Fluorescent quadruple staining for Sox2 (gray), DCX (green), CR (magenta), and $S 100 \beta$ (cyan) in the dentate gyrus. Four types of adult neurogenesis-related cells are defined: $\mathrm{Sox2}^{+} / \mathrm{DCX} \mathrm{X}^{-} / \mathrm{CR}^{-} / \mathrm{S} 100 \beta^{-}$neural stem cells (white asterisks), Sox $2^{-} / D C X^{+} / C R^{-} / S 100 \beta^{-}$neuronal progenitors (white arrowheads), Sox ${ }^{-} / D C X^{+} / C R^{+} / S 100 \beta^{-}$newborn granule cells (white arrows), and Sox $2^{+} / D C X^{-} / C R^{-} / S 100 \beta^{+}$astrocytes (open arrowheads). Mice were treated with $P$-ase $(\boldsymbol{E}), \operatorname{chABC}(\boldsymbol{F}), \operatorname{chAC}(\boldsymbol{G}), \operatorname{orchB}(\boldsymbol{H}) . \boldsymbol{I}-\boldsymbol{L}, \mathrm{NDs}$ of neural stem cells $\left(\boldsymbol{I} ; F_{(3,12)}=1.8013, p=0.2005\right)$, neuronal progenitors $\left(\boldsymbol{J} ; F_{(3,12)}=49.3163, p<\right.$ $0.0001)$, newborn granule cells $\left(\boldsymbol{K} ; F_{(3,12)}=83.5223, p<0.001\right)$, and astrocytes $\left(\boldsymbol{L} ; F_{(3,12)}=0.1360, p=0.9366\right)$ in the dentate gyrus. $\boldsymbol{M}-\boldsymbol{P}$, Fluorescent quadruple staining for Sox2 (gray), DCX (green), $\operatorname{BrdU}$ (magenta), and $\mathrm{S} 100 \beta$ (cyan) in the dentate gyrus of mice that received intradentate injection of P-ase $(\boldsymbol{M}), \operatorname{chABC}(\boldsymbol{N}), \operatorname{chAC}(\boldsymbol{O})$, or chB $(\boldsymbol{P})$, and intraperitoneal injection of BrdU. Two types of proliferating cells are defined: Sox $2^{+} / \mathrm{DCX}^{-} / \mathrm{BrdU} \mathrm{U}^{+} \mathrm{S} 100 \beta^{-}$neural stem cells (white arrowheads) and Sox $2^{-} / \mathrm{DCX}^{+} / \mathrm{BrdU}^{+} / \mathrm{S} 100 \beta^{-}$neuronal progenitors (white arrows). Q, Schematic diagram showing the protocol for BrdU injection. Two weeks after the intradentate injection of enzymatic reagents, mice were treated with intraperitoneal injection of BrdU and killed $24 \mathrm{~h}$ later. $\boldsymbol{R}-\boldsymbol{T}, \mathrm{NDs}$ of total $\operatorname{BrdU}^{+}$proliferating cells $\left(\boldsymbol{R} ; F_{(3,12)}=14.3436, p=0.0003\right), \operatorname{BrdU}{ }^{+}$neural stem cells $\left(\boldsymbol{S} ; F_{(3,12)}=2.1508, p=0.1470\right)$, and BrdU ${ }^{+}$neuronal progenitors $\left(\boldsymbol{T} ; F_{(3,12)}=\right.$ $13.3110, p=0.0004)$ in the dentate gyrus. Data were analyzed by one-way ANOVA with post hoc Tukey's HSD test and are shown as mean \pm SD ( $n=4$ mice in each group). Statistical significance: ${ }^{* *} p<0.01$ (vs. P-ase). Scale bars: $\boldsymbol{B}, 200 \mu \mathrm{m}$ (applies to $\boldsymbol{A}$ and $\boldsymbol{B}$ ); $\mathbf{D 2}, 50 \mu \mathrm{m} ; \boldsymbol{H}, 30 \mu \mathrm{m}$ (applies to $\boldsymbol{E}-\boldsymbol{H}$ and $\boldsymbol{M}-\boldsymbol{P}$ ). 

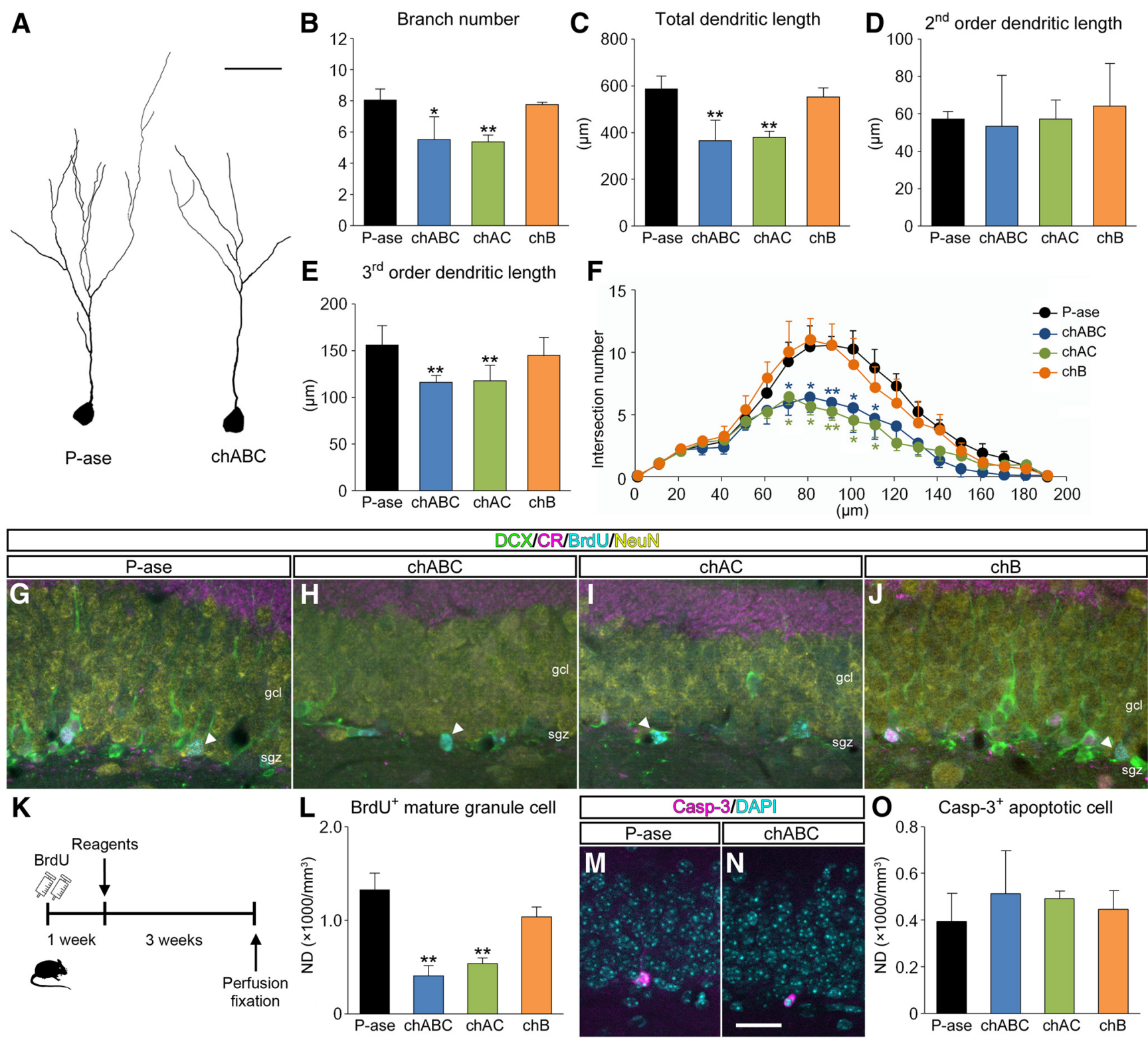

Figure 3. Impairment of maturation of newborn granule cells following CSPG digestion. $A$, Representative reconstruction images showing Sox $2^{-} / D C X^{+} / \mathrm{CR}^{+} / \mathrm{S} 100 \beta^{-}$newborn granule cells in the dentate gyrus of mice treated with P-ase (left) or chABC (right). $\boldsymbol{B}-\boldsymbol{E}$, Morphometric data obtained from 3D reconstruction of the dendrites and cell bodies of newborn granule cells: branch numbers $\left(\boldsymbol{B} ; F_{(3,12)}=0.6292, p=0.6100\right)$, total dendritic length $\left(\boldsymbol{C} ; F_{(3,12)}=24.4539, p=0.0002\right)$, second-order dendritic length $\left(\boldsymbol{D} ; F_{(3,12)}=0.0339, p=0.9912\right)$, and third-order dendritic length $\left(E_{;} F_{(3,12)}=5.5738, p=0.0125\right)$. $\boldsymbol{F}$, Sholl analysis of the dendritic morphologies of newborn granule cells. The numbers of intersections at $70 \mu \mathrm{m}\left(F_{(3,12)}=7.3223, p=0.0048\right), 80 \mu \mathrm{m}$ $\left(F_{(3,12)}=23.9210, p<0.0001\right), 90 \mu \mathrm{m}\left(F_{(3,12)}=22.8820, p<0.0001\right), 100 \mu \mathrm{m}\left(F_{(3,12)}=10.8076, p=0.0010\right)$, and $110 \mu \mathrm{m}\left(F_{(3,12)}=6.9502, p=0.00577\right)$ from the cell body are lower in mice treated with chABC or chAC than in mice treated with P-ase. G-J, Based on the fluorescent quadruple staining for DCX (green), CR (magenta), BrdU (cyan), and NeuN (yellow), DCX ${ }^{-} / C^{-} /$ $\mathrm{BrdU}^{+} / \mathrm{NeuN}^{+}$mature granule cells (white arrowheads) are defined in the dentate gyrus of mice treated with P-ase $(\boldsymbol{G}), \operatorname{chABC}(\boldsymbol{H}), \operatorname{chAC}(\boldsymbol{I})$, or chB $(\boldsymbol{J}) . \boldsymbol{K}$, Schematic diagram of the experiment. One week after intraperitoneal injection of BrdU, mice were treated with $\mathrm{P}$-ase, chABC, chAC, or chB and killed 3 weeks later. $L, N D$ s of BrdU ${ }^{+}$mature granule cells in the dentate gyrus of mice treated with different enzymatic reagents $\left(F_{(3,12)}=40.6887, p<0.0001\right) . M, N$, Fluorescent staining for Casp-3 (magenta) and DAPI (cyan) in the dentate gyrus of mice treated with P-ase $(\boldsymbol{M})$ or chABC $(\boldsymbol{N}) . \mathbf{O}$, NDs of Casp-3 ${ }^{+}$apoptotic cells in the dentate gyrus of mice treated with different enzymatic reagents $\left(F_{(3,12)}=2.4941, p=0.1097\right)$. Data were analyzed by one-way ANOVA with post hoc Tukey's HSD test and are shown as mean \pm SD ( $n=4$ mice in each group). Statistical significance: ${ }^{*} p<0.05$, ${ }^{* *} p<0.01$ (vs. P-ase). Scale bars: $\boldsymbol{A}, 30 \mu \mathrm{m} ; \boldsymbol{N}, 30 \mu \mathrm{m}$ (applies to $\mathbf{G}-\boldsymbol{J}, \mathbf{M}$, and $\boldsymbol{N}$ ).

\section{Impairment of newborn granule cell maturation following CSPG digestion}

To analyze the effects of CSPG digestion on maturation of newborn granule cells, their dendritic morphologies were evaluated quantitatively by $3 \mathrm{D}$ reconstruction. Compared with $\mathrm{P}$-ase-treated mice, the dendritic arbors of newborn granule cells were generally shortened and simplified in chABCtreated mice (Fig. 3A). The branch numbers (Fig. 3B), total dendritic length (Fig. 3C), second-order dendritic length (Fig. $3 D$ ), third-order dendritic length (Fig. 3E), and intersection numbers of dendrites at 70-110 $\mu \mathrm{m}$ from the cell body (Sholl analysis; Fig. $3 F$ ) were lower in mice treated with chABC or chAC than in mice treated with $\mathrm{P}$-ase or chB. These findings indicate that maturation of newborn granule cells is impaired by digestion of CSPG.

To identify the effects of CSPG digestion on production of mature newborn granule cells, sections were immunostained for DCX, CR, BrdU, and NeuN (Fig. 3G-J). One week after the intraperitoneal injection of $\mathrm{BrdU}$, animals received intradentate injection of $\mathrm{P}$-ase, chABC, chAC, or chB and were killed 3 weeks 

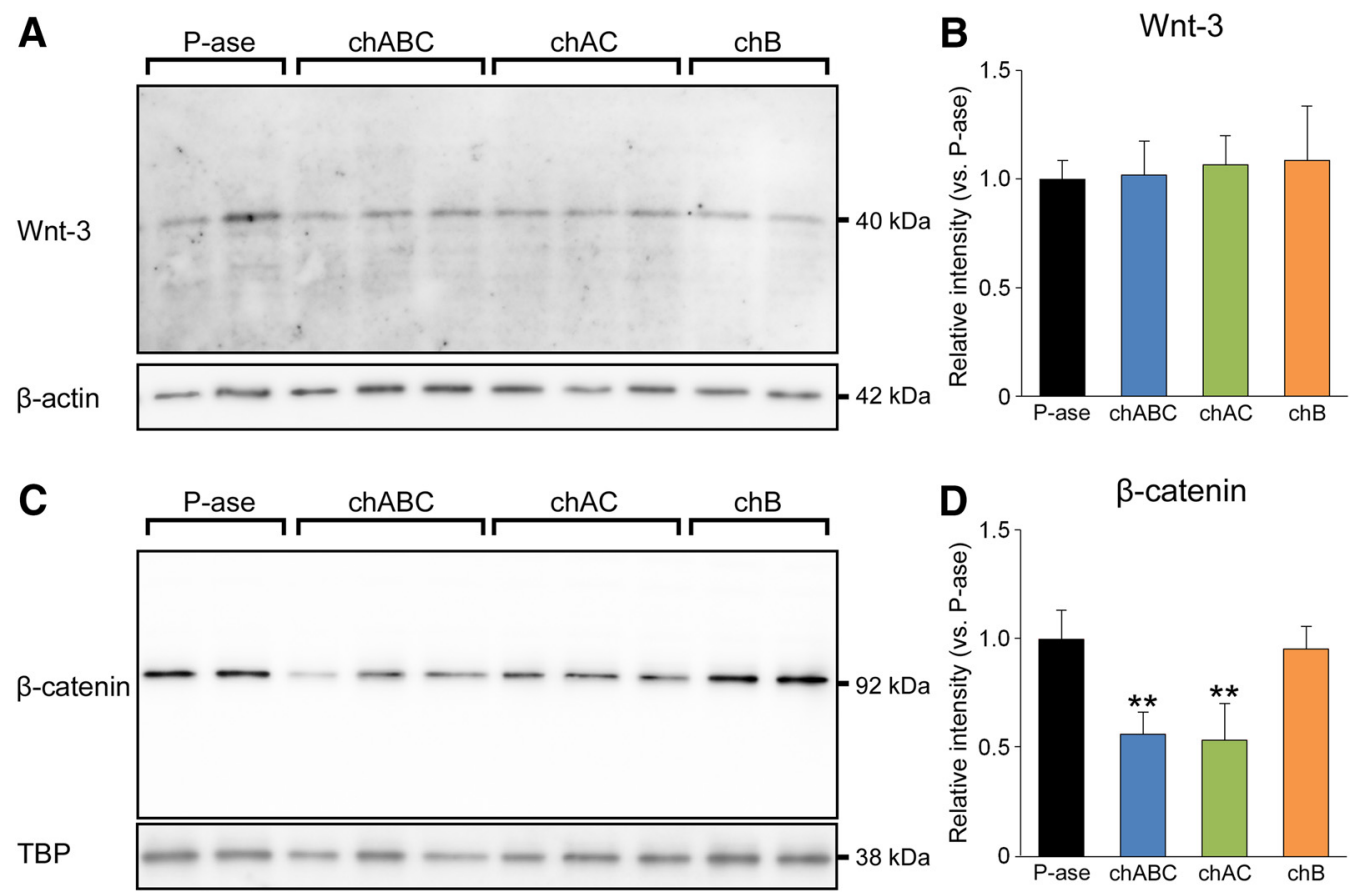

Figure 4. Reduction in the expression level of $\beta$-catenin in the dentate gyrus following CSPG digestion. $\boldsymbol{A}, \boldsymbol{B}$, Western blots $(\boldsymbol{A})$ and band intensities (B) of Wnt- 3 in the dentate gyrus of mice treated with P-ase, chABC, chAC, or chB $\left(F_{(3,20)}=0.8959, p=0.4605\right)$. $C, D$, Western blots $(C)$ and the band intensities $(\boldsymbol{D})$ of $\beta$-catenin in the dentate gyrus of mice received the same treatment $\left(F_{(3,20)}=21.6999, p<0.0001\right)$. Data were analyzed by one-way ANOVA with post hoc Tukey's HSD test and are shown as mean \pm SD $(n=6$ mice in each group). Statistical significance: ** $p<$ 0.01 (vs. P-ase).

later (Fig. $3 \mathrm{~K}$ ). The $\mathrm{NDs}$ of $\mathrm{DCX}^{-} / \mathrm{CR}^{-} / \mathrm{BrdU}^{+} / \mathrm{NeuN}^{+}$mature newborn granule cells were lower in mice treated with chABC or chAC than in mice treated with $\mathrm{P}$-ase or chB (Fig. $3 L$ ). Using the same animals, the potential effects of CSPG digestion on apoptosis were also estimated by immunostaining for Casp-3 (Fig. $3 M, N)$. Despite the reduction in mature newborn granule cells, the NDs of Casp- $3^{+}$apoptotic cells in the dentate gyrus were not affected by treatment with chABC or chAC (Fig. 3O).

\section{Reduction in $\boldsymbol{\beta}$-catenin expression following CSPG digestion} Previous studies have reported that CSPG is required for efficient Wnt-3 signaling (Nadanaka et al., 2008), which may also underlie the regulation of adult hippocampal neurogenesis. To address whether digestion of CSPG affects the canonical Wnt signaling pathway, we analyzed the expression levels of Wnt-3 and $\beta$ catenin by Western blotting. The band intensities of Wnt-3 were comparable among mice treated with $\mathrm{P}$-ase, chABC, chAC, or chB (Fig. $4 A, B$ ). By contrast, the band intensities of $\beta$-catenin were lower in mice treated with chABC or chAC than in mice treated with $\mathrm{P}$-ase or chB (Fig. $4 C, D$ ).

\section{Impairment of cognitive memory following CSPG digestion}

To examine the effects of CSPG digestion on mouse behaviors, mice were evaluated by OFT and NORT (Fig. 5A1,A2). Administration of enzymatic reagents did not affect the behavioral parameters obtained from OFT: the time (in seconds) spent in the center area (Fig. $5 B$ ) and the outer zone (Fig. $5 C$ ), the ratios of time spent in the center area versus the outer zone (Fig. 5D), and the total distance traveled (meter) (Fig. 5E).

Because adult hippocampus neurogenesis is shown to be involved in cognitive memory, mice were then subjected to NORT (Jessberger et al., 2009; Sakalem et al., 2017) (Fig. 5F-H). During the familiarization session, $\mathrm{P}$-ase-treated control mice showed no difference in time spent exploring objects 1 and 2 (Fig. $5 F$ ). Sim- ilar results were obtained from mice treated with chABC, chAC, or chB. Then, during the test session, mice treated with $\mathrm{P}$-ase or chB explored the novel object longer than the unchanged object (Fig. 5G). However, there were no differences in the exploration behavior in mice treated with chABC or chAC. We then calculated the discrimination index and found that this parameter was improved in mice treated with $\mathrm{P}$-ase or $\mathrm{chB}$, but remained unchanged (close to 0 ) in mice treated with chABC or chAC (Fig. $5 H$ ).

\section{Increase in CSPG and promotion of adult hippocampal neurogenesis by $\mathrm{EE}$}

We examined the involvement of CSPG digestion in experiencedependent modulation of adult hippocampal neurogenesis. In this experiment, mice were housed in an EE or subjected to forced swim stress for 2 weeks and were then killed for HPLC or IHC (Fig. 6A). Using HPLC, we examined the amount of chondroitin-4-sulfate (CS-4) and chondroitin-6-sulfate (CS6 ), which are known to be the two most common sulfation patterns of CSPG (Miyata et al., 2012). The amount of CS-4 was higher in mice housed in an EE and lower in mice exposed to forced swim stress (Fig. 6B). The amount of CS-6 was higher in mice housed in an EE compared with mice exposed to forced swim stress (Fig. 6C). The amount of total CSPG was higher in mice housed in an EE than in mice exposed to forced swim stress (Fig. 6D).

In accordance with the results obtained from the HPLC analysis, the staining of WFA appeared generally enhanced by EE and decreased by forced swim stress (Fig. $6 E-G$ ). The fluorescence intensities of WFA were higher in mice housed in an EE and lower in mice exposed to forced swim stress (Fig. 6H). Because WFA mainly recognizes CS-4 (Miyata and Kitagawa, 2016), these findings indicate that the alterations in the fluorescence intensities of WFA may correlate with the amount of CS-4. 


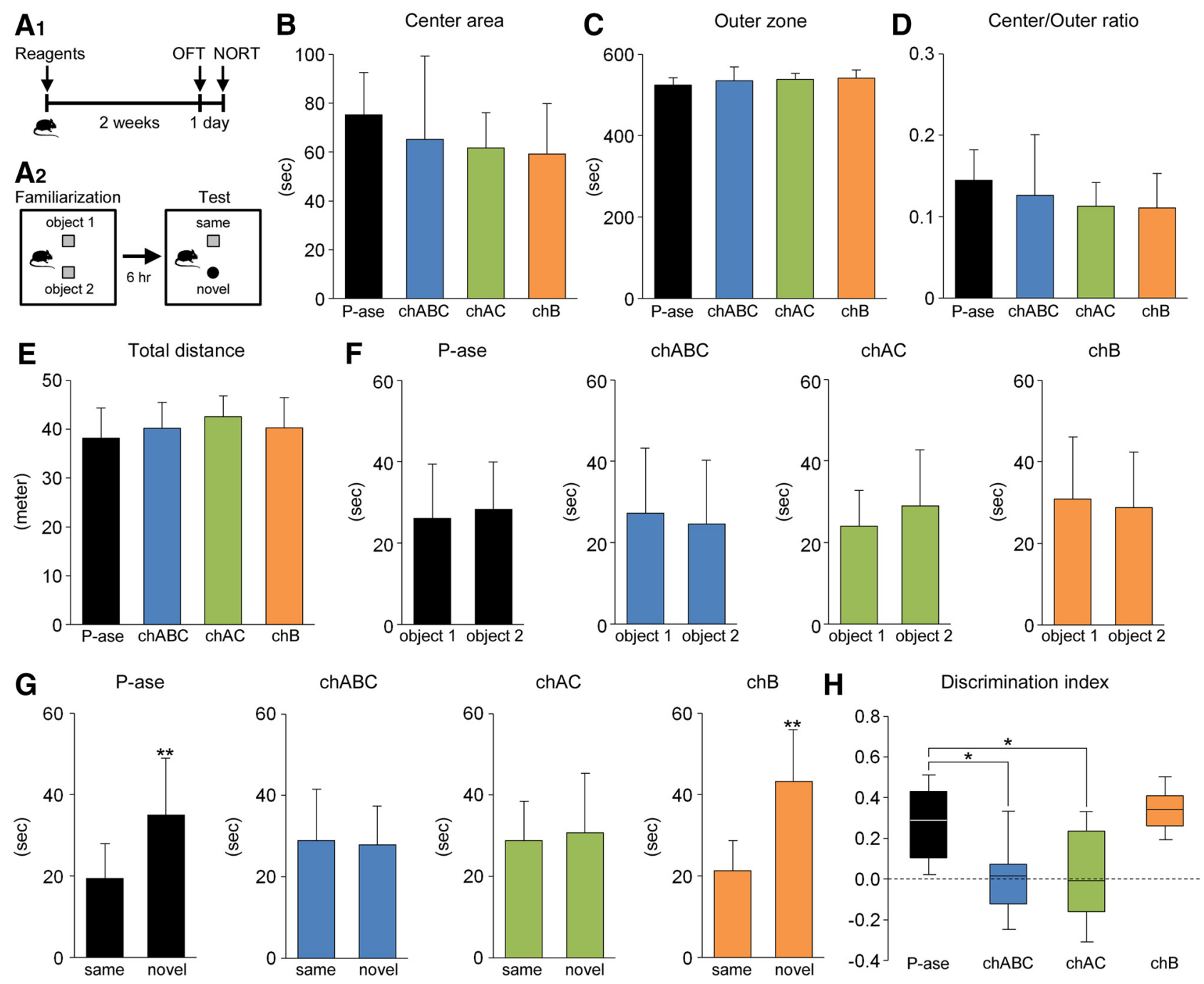

Figure 5. Impairment of cognitive memory following CSPG digestion. $A$, Schematic diagram of the behavior experiment. Two weeks after the intradentate injection of $P$-ase, chABC, chAC, or chB, mice were evaluated by OFT (A1). The next day, the same animals were subjected to NORT (A2). In the test session ( $6 \mathrm{~h}$ after the familiarization session), object 2 was changed to a novel object. $\boldsymbol{B}$ - $\boldsymbol{D}$, Time (in seconds) spent in the center area $\left(\boldsymbol{B} ; F_{(3,45)}=2.2696, p=0.0933\right)$ and the outer zone $\left(\boldsymbol{C} ; F_{(3,45)}=2.2696, p=0.0933\right)$ of the open-field apparatus and the ratio of time spent in center area/outer zone $\left(\boldsymbol{D} ; F_{(3,45)}=2.2558, p=0.0948\right) . \boldsymbol{E}$, Total distance of traveled (in meters) of mice treated with $\mathrm{P}$-ase, chABC, chAC, or chB $\left(F_{(3,45)}=1.2529, p=0.3019\right) . \boldsymbol{F}$, Time (in seconds) spent exploring the object 1 and 2 during the familiarization session in mice treated with different enzymatic reagents $\left(P\right.$-ase, $t_{(18.30)}=0.3008, p=0.767 ; c h A B C, t$, $t_{(21.99)}=0.4100, p=0.6857 ;$ chAC, $\left.t_{(18.49)}=1.0337 p=0.3416 ; \mathrm{chB}, t_{(23.73)}=0.3945, p=0.6967\right)$. Data were analyzed by Welch's test and are shown as mean \pm SD (P-ase, $n=12$ mice; chABC, $n=12$ mice; chAC, $n=12$ mice; chB, $n=13$ mice). G, Time (in seconds) spent exploring the (same and novel) objects during the test session in mice treated with different enzymatic reagents $\left(P\right.$-ase, $t_{(18.26)}=3.3041, p=0.0038$; $\left.\operatorname{chABC}, t_{(20.45)}=0.2269, p=0.8227 ; \mathrm{chAC}, t_{(19.02)}=0.3714, p=0.7144 ; \mathrm{chB}, t_{(18.62)}=5.1287, p<0.0001\right)$. Data were analyzed by Welch's $t$ test and are shown as mean \pm SD (P-ase, $n=$ 12 mice; chABC, $n=12$ mice; chAC, $n=12$ mice; chB, $n=13$ mice). $\boldsymbol{H}$, Using the same dataset, the discrimination index (time spent with the novel object - time spent with the same object)/(total time exploring both objects) was calculated for each mouse $\left(F_{(3,45)}=11.1290, p<0.0001\right)$. Discrimination indices of 0 indicate equal exploration of both objects. The central rectangle spans the first quartile to the third quartile. The segment in the rectangle shows the median. The whiskers above and below the box show the locations of the minimum and maximum. Data were analyzed by one-way ANOVA with post hoc Tukey's HSD test. Statistical significance: ${ }^{*} p<0.05$, ${ }^{* *} p<0.01$ (vs. same for $\mathbf{G}$; vs. P-ase for $\boldsymbol{H}$ ).

Quadruple-labeled fluorescence images (Sox2, DCX, CR, and $S 100 \beta$ ) of the dentate gyrus were obtained from control mice (Fig. 6I), mice housed in an EE (Fig. 6J), and mice exposed to forced swim stress (Fig. $6 \mathrm{~K}$ ). The NDs of neural stem cells (Fig. $6 L$ ), neuronal progenitors (Fig. $6 M$ ), and newborn granule cells (Fig. $6 \mathrm{~N}$ ) were higher in mice housed in an $\mathrm{EE}$ and lower in mice exposed to forced swim stress. The NDs of astrocytes were not affected by the experiences of the animals (Fig. 6O).

\section{Restoration of adult hippocampal neurogenesis by EE subsequent to CSPG digestion}

We investigated whether EE could counteract chondroitinaseinduced impairment of adult hippocampal neurogenesis (Fig. 7). In this experiment, mice received intradentate injection of enzy- matic reagents were killed after having been housed for 2 weeks in an EE or in standard conditions (Fig. 7A). WFA staining was detected in the dentate gyrus of chABC (EE) mice, but was weak in the dentate gyrus of chABC (STD) mice (Fig. 7 B,C). The fluorescence intensities of WFA in the dentate gyrus were higher in $\mathrm{P}$-ase (EE) mice, chABC (EE) mice, and chAC (EE) mice than in chABC (STD) mice (Fig. 7D). Considered together, these findings indicate that the recovery of expression of CSPG from the pharmacological depletion may be accelerated by EE.

Quadruple-labeled fluorescence images (Sox2, DCX, CR, and $\mathrm{S} 100 \beta)$ of the dentate gyrus were obtained from $\mathrm{P}$-ase (EE) mice (Fig. 7E), chABC (EE) mice (Fig. 7F), chAC (EE) mice (Fig. 7G), and chB (EE) mice (Fig. 7H). The NDs of neuronal progenitors 
A

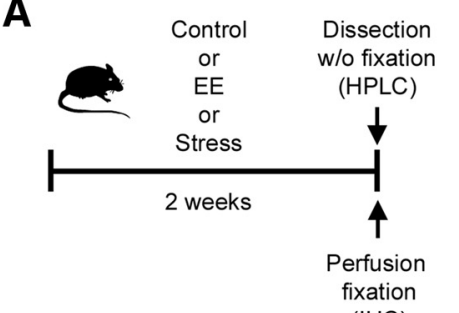

(IHC)

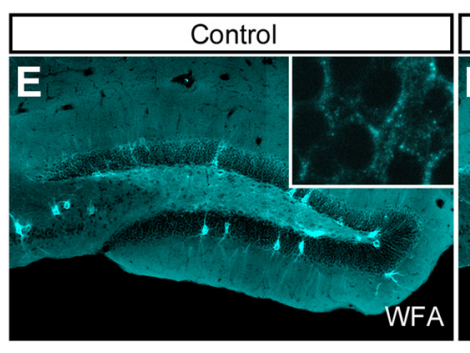

B

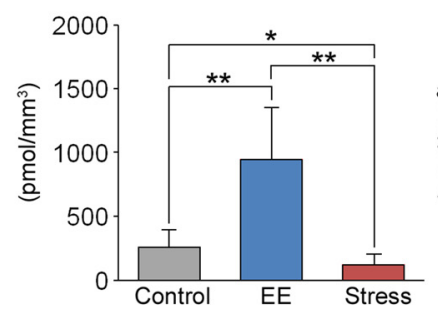

Chondroitin 4-sulfation

$$
\text { i. }
$$



\section{(50}

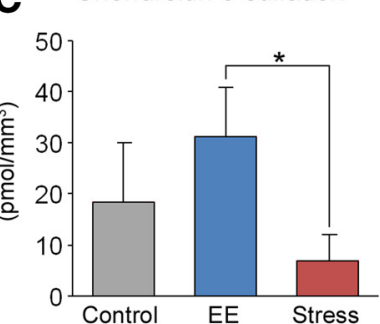

D Total chondroitin sulfate

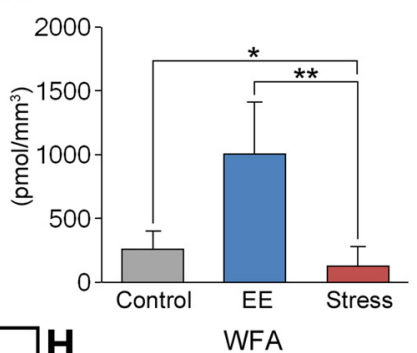

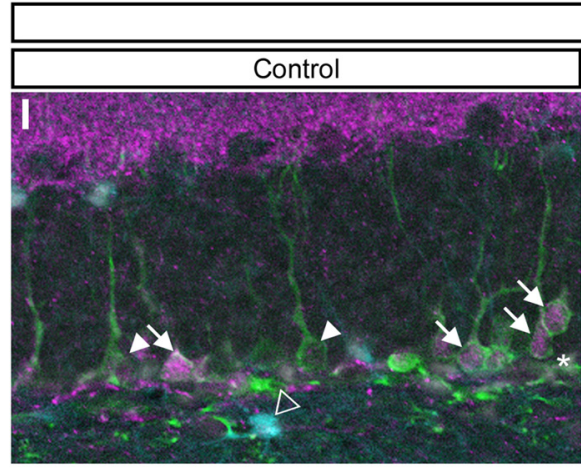

L

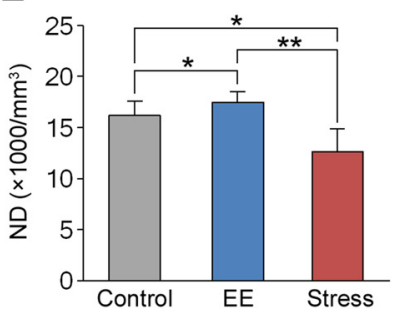

M

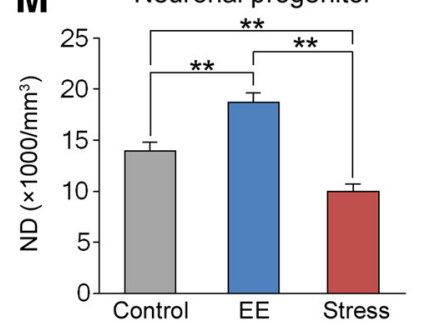

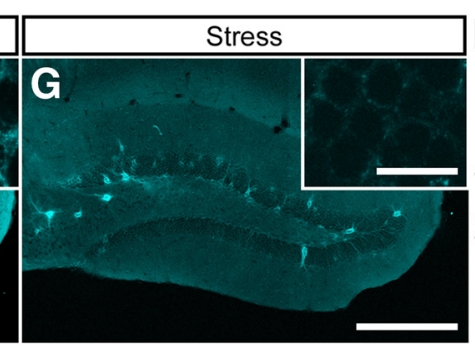

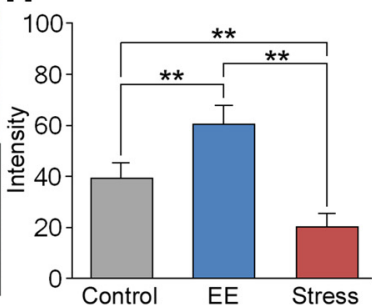

SOX2/DCX/CR/S100B
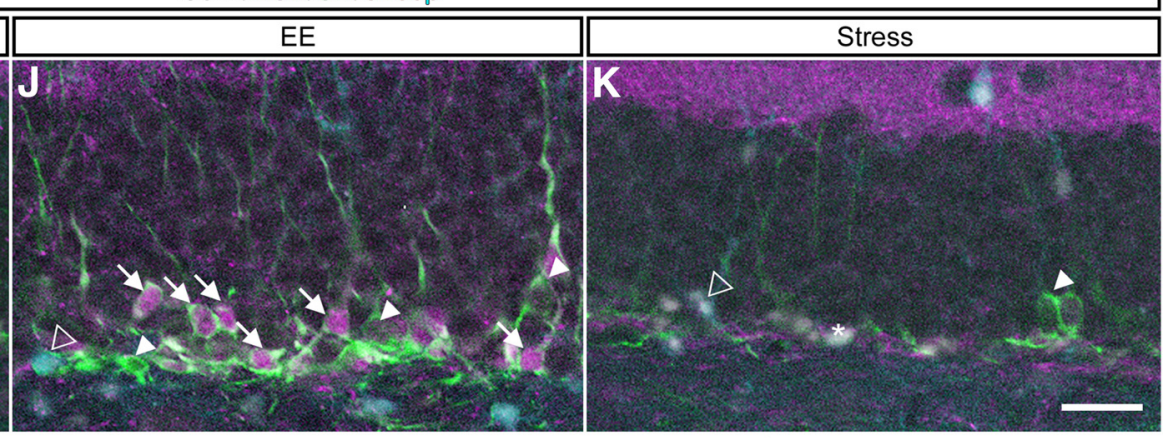

N

Newborn granule cell



0

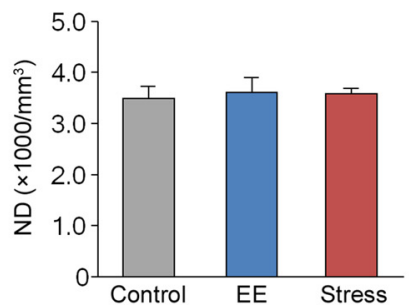

Figure 6. Increase in the expression levels of CSPG in the dentate gyrus by EE. $A$, Schematic diagram of the experiment to see the effect of housing conditions on CSPG in the hippocampus. Mice were housed in standard conditions (control), subjected to forced swim stress (stress), or housed in an EE for 2 weeks, after which they were killed for HPLC or IHC. $\boldsymbol{B}-\boldsymbol{D}$, The amount of CS-4 (B; $\left.\mathrm{pmol} / \mathrm{mm}^{3} ; F_{(2,10)}=14.7782, p=0.0010\right),\left(\mathrm{CS}-6\left(\boldsymbol{C}, \mathrm{pmol} / \mathrm{mm}^{3} ; F_{(2,10)}=6.9297, p=0.0129\right)\right.$, and total CSPG $\left(\boldsymbol{D} ; \mathrm{pmol} / \mathrm{mm}^{3} ; F_{(2,10)}=14.5957, p=0.0011\right)$ in the dentate gyrus. Data were analyzed by one-way ANOVA with post hoc Tukey's HSD test and are shown as mean \pm SD (control, $n=5$ mice; EE, $n=4$ mice, stress, $n=4$ mice). $\boldsymbol{E}-\boldsymbol{G}$, Fluorescence images of WFA ${ }^{+}$CSPG (cyan)

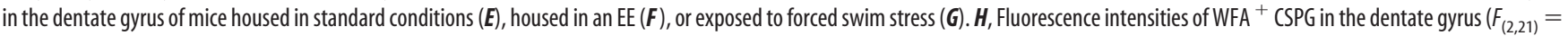
$126.0423, p<0.0001)$. Data were analyzed by one-way ANOVA with post hoc Tukey's HSD test and are shown as mean $\pm S D$ ( $n=8$ mice in each group). $I-K$, Fluorescent quadruple staining for Sox2 (gray), DCX (green), CR (magenta), and S100 $\beta$ (cyan) in the dentate gyrus of mice housed in standard conditions ( $\boldsymbol{I}$ ), housed in an EE $(\boldsymbol{J})$, or exposed to forced swim stress (K). Four types of adult neurogenesis-related cells are defined as follows: Sox $2^{+} / \mathrm{DCX} X^{-} / \mathrm{CR}^{-} / \mathrm{S} 100 \beta^{-}$neural stem cells (white asterisks), Sox $2^{-} / \mathrm{DCX} \mathrm{X}^{+} / \mathrm{CR}^{-} / \mathrm{S} 100 \beta^{-}$neuronal progenitors (white arrowheads), Sox $2^{-} / D C X^{+} / C R^{+} / S 100 \beta^{-}$newborn granule cells (white arrows), and Sox $2^{+} / D C X-/ C R^{-} / S 100 \beta^{+}$astrocytes (open arrowheads). $L-0$, NDs of neural stem cells $\left(L ; F_{(2,21)}=22.5541, p<\right.$ $0.0001)$, neuronal progenitors $\left(\boldsymbol{M} ; F_{(2,21)}=32.7305, p<0.0001\right)$, newborn granule cells $\left(\boldsymbol{N} ; F_{(2,21)}=294.4005, p<0.0001\right)$, and astrocytes $\left(\boldsymbol{0} ; F_{(2,21)}=0.7413, p=0.4885\right)$ in the dentate gyrus. Data were analyzed by one-way ANOVA with post hoc Tukey's HSD test and are shown as mean $\pm S D\left(n=8\right.$ mice in each group). Statistical significance: ${ }^{*} p<0.05$, ${ }^{* *} p<0.01$ (between groups). Scale bars: $\mathbf{G}, 200 \mu \mathrm{m}$ (applies to $\boldsymbol{E}-\boldsymbol{G}$ ); inset of $\mathbf{G}, 20 \mu \mathrm{m}$ (applies to insets of $\boldsymbol{E}-\boldsymbol{G}$ ); $\boldsymbol{K}, 30 \mu \mathrm{m}$ (applies to $\boldsymbol{I}-\boldsymbol{J}$ ).

and newborn granule cells were lower in chABC (EE) mice and chAC (EE) mice than in P-ase (EE) mice (Fig. $7 \mathrm{~J}, \mathrm{KK}$ ). The NDs of neural stem cells and astrocytes were not affected by the digestion of CSPG (Fig. 7I,L).

The effect of EE on restoration of neurogenesis was calculated by dividing the NDs of mice housed in an EE by the NDs of mice kept in standard conditions. The promotion ratios of EE (fold difference between EE and STD) in neural stem cells and astrocytes were comparable among the four groups (Fig. $7 M, P)$. The promotion ratios of $\mathrm{EE}$ in neuronal progenitors and newborn granule cells were higher in mice treated with chABC or chAC than in mice treated with P-ase (Fig. $7 \mathrm{~N}, \mathrm{O}$ ). In summary, these findings suggest that the restoration of granule cell production after the pharmacological depletion of CSPG may also be promoted by EE.

\section{Lack of effects of EE on adult hippocampal neurogenesis in T1KO mice}

We analyzed T1KO mice that lacked the gene encoding the key enzyme for CSPG synthesis, CSGalNAcT1 (Fig. 8). Bone devel- 
A

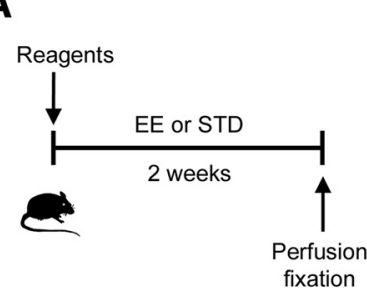

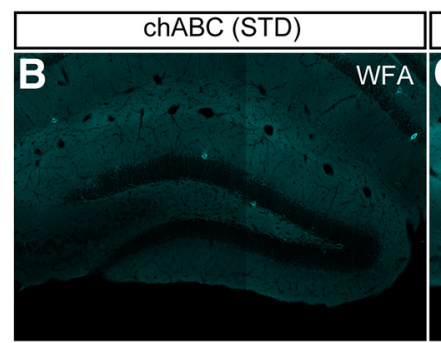
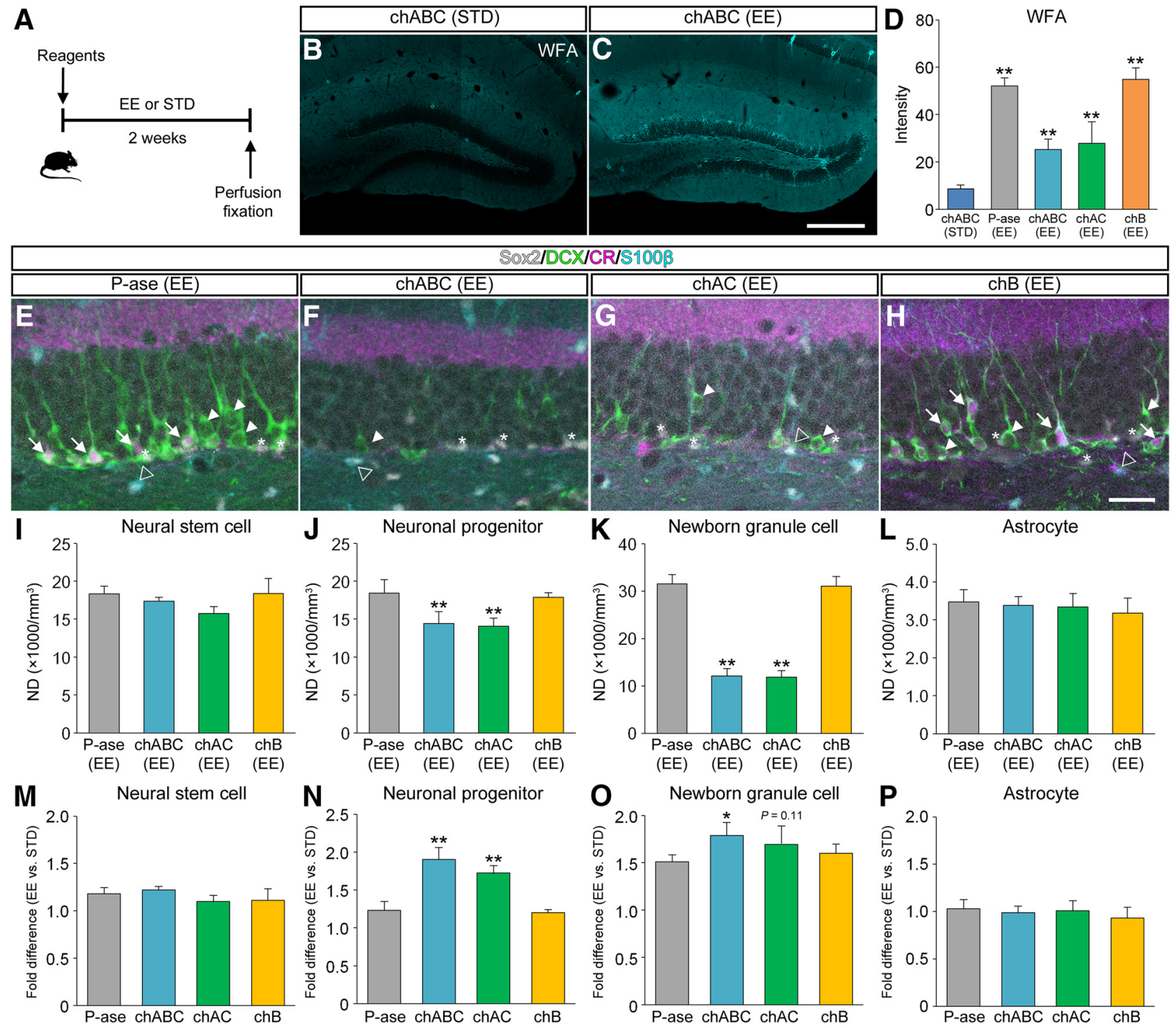

Figure 7. Restoration of adult hippocampal neurogenesis by EE subsequent to CSPG digestion. $A$, Schematic diagram of the experiment to see the recovery effects of EE on declined neurogenesis. Mice treated with $\mathrm{P}$-ase, chABC, chAC, or chB were housed in different conditions for 2 weeks and then perfusion fixed for IHC. $B$, C, Fluorescence images showing WFA ${ }^{+}$CSPG (cyan) in the dentate gyrus of chABC (STD) mice $(\boldsymbol{B})$ and chABC (EE) mice (C). D, Fluorescence intensities of WFA ${ }^{+}$CSPG in the dentate gyrus of chABC (STD) mice, P-ase (EE) mice, chABC (EE) mice, chAC (EE) mice, and chB (EE) mice $\left(F_{(4,15)}=63.7864, p<0.0001\right) . \boldsymbol{E}-\boldsymbol{H}$, Fluorescent quadruple staining for Sox2 (gray), DCX (green), CR (magenta), and S100 $\beta$ (cyan) in the dentate gyrus of P-ase (EE) mice (E), chABC (EE) mice $(\boldsymbol{F})$, chAC (EE) mice $(\boldsymbol{G})$, or chB (EE) mice $(\boldsymbol{H})$. Four types of adult neurogenesis-related cells are defined as follows: Sox2 ${ }^{+} / \mathrm{DCX}{ }^{-} / \mathrm{CR}^{-} / \mathrm{S} 100 \beta^{-}$neural stem cells (white asterisks), Sox $2^{-} / D C X^{+} / C R^{-} / S 100 \beta^{-}$neuronal progenitors (white arrowheads), Sox ${ }^{-} / D C X^{+} / \mathrm{CR}^{+} / \mathrm{S} 100 \beta^{-}$newborn granule cells (white arrows), and Sox ${ }^{+} / D C X^{-} / C R^{-} / S 100 \beta^{+}$astrocytes (open arrowheads). $\boldsymbol{I}-\boldsymbol{L}$, NDs of neural stem cells $\left(\boldsymbol{I} ; F_{(3,12)}=3.4379, p=0.0520\right)$, neuronal progenitors $\left(\boldsymbol{J} ; F_{(3,12)}=11.6978, p=0.0007\right)$, newborn granule cells $\left(\boldsymbol{K} ; F_{(3,12)}=164.9622, p<\right.$ $0.0001)$, and astrocytes $\left(\boldsymbol{L} ; F_{(3,12)}=0.5168, p=0.6785\right)$ in the dentate gyrus of mice treated with different enzymatic reagents and housed in an EE. $\boldsymbol{M}-\boldsymbol{P}$, Promotion ratios (fold difference between EE and STD) calculated for neural stem cells $\left(\boldsymbol{M} ; F_{(3,12)}=2.1149, p=0.1517\right)$, neuronal progenitors $\left(\boldsymbol{N} ; F_{(3,12)}=43.0701, p<0.0001\right)$, newborn granule cells $\left(\boldsymbol{O} ; F_{(3,12)}=8.2306, p=0.0030\right)$, and astrocytes $\left(\boldsymbol{P} ; F_{(3,12)}=0.7371, p=0.5497\right)$. To calculate the ratios, the NDs of mice house in standard conditions were obtained from Figure $21-L$. Data were analyzed by one-way ANOVA with post hoc Tukey's HSD test and are shown as mean \pm SD ( $n=4$ mice in each group). Statistical significance: ${ }^{* *} p<0.01$ [vs. chABC (STD) for $D$ ] ; ${ }^{*} p<0.05$, ${ }^{* *} p<0.01$ [vs. P-ase (EE) for $I-L$; vs. P-ase for $\boldsymbol{M}-\boldsymbol{P}$ ). Scale bars: $\boldsymbol{C}, 200 \mu \mathrm{m}$ (applies to $\boldsymbol{B}$ and $\boldsymbol{C}$ ); $\boldsymbol{H}, 30 \mu \mathrm{m}$ (applies to $\boldsymbol{E}-\boldsymbol{H}$ ).

opment of T1KO mice is slightly impaired and their body size is $10 \%$ smaller than that of WT mice (Watanabe et al., 2010; Sato et al., 2011). A recent HPLC analysis has reported that the amount of CSPG is reduced by $\sim 50 \%$ in various brain regions of $\mathrm{T} 1 \mathrm{KO}$ mice (Yoshioka et al., 2017).

To analyze the involvement of CSGalNAcT1 in the effects of $\mathrm{EE}, \mathrm{WT}$ mice and T1KO mice were housed under an EE or in standard conditions for 2 weeks. As mentioned above, the staining of WFA in the dentate gyrus appeared stronger in WT (EE) mice compared with WT (STD) mice (Fig. $8 A, C$ ). By contrast, the staining of WFA in the dentate gyrus was very weak in both T1KO (STD) mice and T1KO (EE) mice (Fig. 8B,D). The fluorescent intensity analysis of WFA confirmed these observations (Fig. 8I).

Quadruple-labeled fluorescence images (Sox2, DCX, CR, and $\mathrm{S} 100 \beta)$ of the dentate gyrus were obtained from WT (STD) mice (Fig. $8 E$ ), T1KO (STD) mice (Fig. 8F), WT (EE) mice (Fig. 8G), and T1KO (EE) mice (Fig. $8 H$ ). There were no differences in the NDs of neural stem cells and neuronal progenitors between WT (STD) mice and T1KO (STD) mice (Fig. $8 \mathrm{~J}, \mathrm{~K}$ ). However, the NDs of newborn granule cells were lower in T1KO (STD) mice than in WT (STD) mice (Fig. 8L). The NDs of neural stem cells, neuronal progenitors, and newborn granule cells 


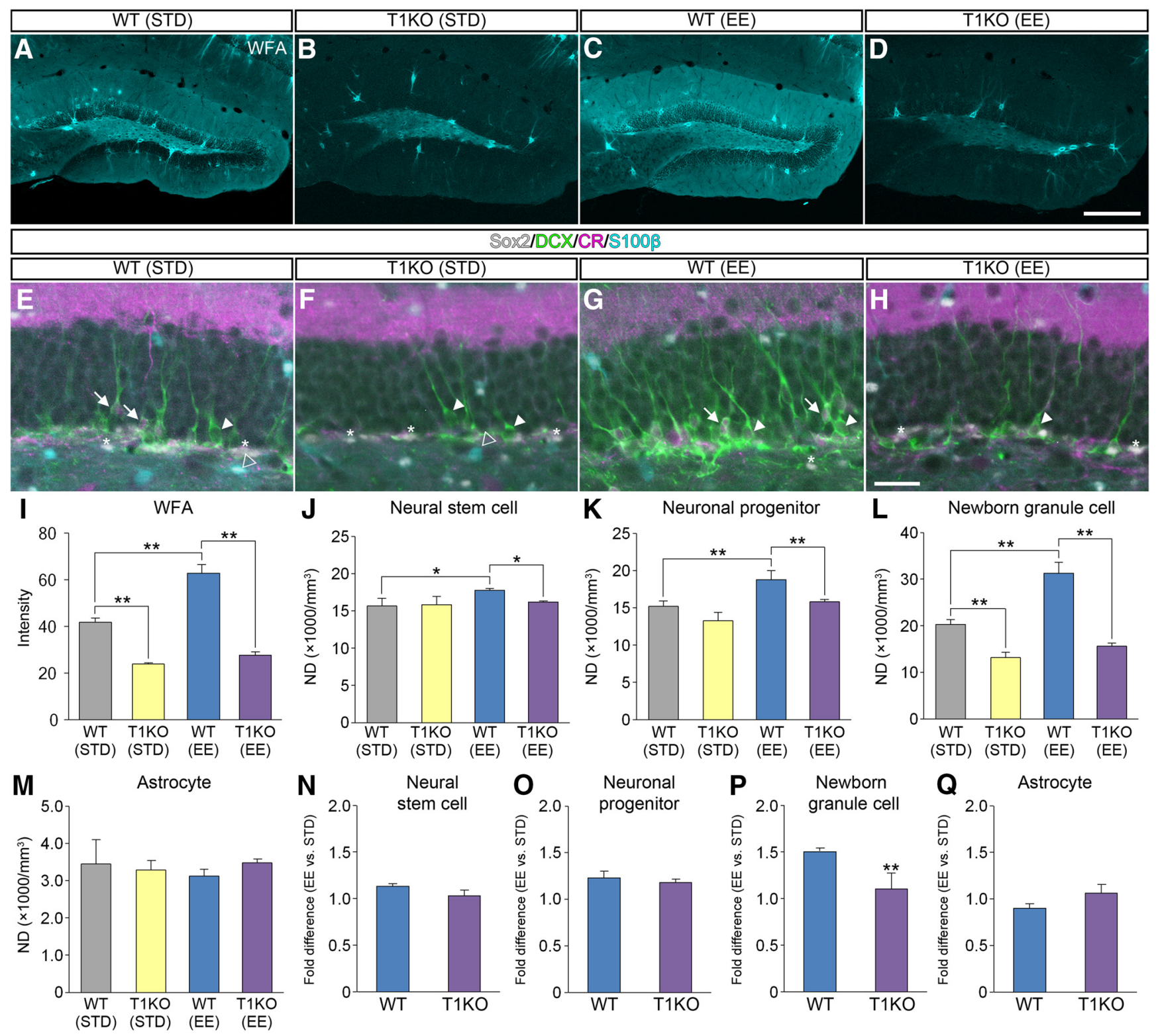

Figure 8. Lack of effects of EE on adult hippocampal neurogenesis in T1K0 mice. $\boldsymbol{A}-\boldsymbol{D}$, Fluorescence images of WFA ${ }^{+}$CSPG (cyan) in the dentate gyrus of WT (STD) mice ( $\left.\boldsymbol{A}\right)$, T1K0 (STD) mice ( $\left.\boldsymbol{B}\right)$, WT (EE) mice (C), and T1KO (EE) mice (D). $\boldsymbol{E}-\boldsymbol{H}$, Fluorescent quadruple staining for Sox2 (gray), DCX (green), CR (magenta), and S100 $\beta$ (cyan) in the dentate gyrus of WT (STD) mice (E), T1KO (STD) mice $(\boldsymbol{F})$, WT (EE) mice $(\boldsymbol{G})$, and T1KO (EE) mice $(\boldsymbol{H})$. Four types of adult neurogenesis-related cells are defined: Sox2 ${ }^{+} / \mathrm{DCX} \mathrm{X}^{-} / \mathrm{CR}^{-} / \mathrm{S} 100 \beta^{-}$neural stem cells (white asterisks), Sox2 ${ }^{-} / \mathrm{DCX}{ }^{+} /$ $C R^{-} / S 100 \beta^{-}$neuronal progenitors (white arrowheads), Sox $2^{-} / D C X^{+} / C R^{+} / S 100 \beta^{-}$newborn granule cells (white arrows), and Sox $2^{+} / D C X^{-} / C^{-} / S 100 \beta^{+}$astrocytes (open arrowheads). $\mathbf{I}$, Fluorescence intensities of WFA ${ }^{+}$CSPG in the dentate gyrus of the four groups of mice $\left(I ; F_{(3,12)}=469.7401, p<0.0001\right) . J-M$, NDs of neural stem cells $\left(J ; F_{(3,12)}=6.2300, p=0.0085\right)$, neuronal progenitors $\left(\boldsymbol{K} ; F_{(3,12)}=15.8166, p=0.0002\right)$, newborn granule cells $\left(\boldsymbol{L} ; F_{(3,12)}=82.7433, p<0.0001\right)$, and astrocytes $\left(M ; F_{(3,12)}=0.8207, p=0.50713\right)$ in the dentate gyrus of mice treated with different enzymatic reagents. Data were analyzed by one-way ANOVA with post hoc Tukey's HSD test and are shown as mean \pm SD ( $n=4$ mice in each group). $\boldsymbol{N}-\boldsymbol{Q}$, Promotion ratios (fold difference between EE and. STD) calculated for neural stem cells $\left(\boldsymbol{N} ; t_{(4.42)}=4.1958, p=0.1110\right)$, neuronal progenitors $\left(\mathbf{0} ; t_{(4.64)}=1.3199, p=0.2481\right)$, newborn granule cells $\left(\boldsymbol{P} ; t_{(3.25)}=\right.$ $6.9957, p=0.0046)$, and astrocytes $\left(\boldsymbol{Q} ; t_{(5.99)}=1.5236, p=0.1785\right)$. Data were analyzed by Welch's $t$ test and are shown as mean $\pm S D\left(n=4\right.$ mice in each group). Statistical significance: ${ }^{*} p<$ $0.05,{ }^{* *} p<0.01$ (between groups for $\boldsymbol{I}-\boldsymbol{M} ;$ vs. WT for $\boldsymbol{N}-\mathbf{Q}$ ). Scale bars: $\boldsymbol{D}, 200 \mu \mathrm{m}$ (applies to $\boldsymbol{A}-\boldsymbol{D}$ ); $\boldsymbol{H}, 30 \mu \mathrm{m}$ (applies to $\boldsymbol{E}-\boldsymbol{H}$ ).

were lower in T1KO (EE) mice than in WT (EE) mice. There were no differences in the NDs of astrocytes among the four groups (Fig. 8M).

The involvement of CSGalNAcT1 in the effects of EE on neurogenesis was estimated by dividing the NDs of mice housed in an EE by those kept in standard conditions. The promotion ratios of EE (fold difference between EE and STD) in neural stem cells (Fig. $8 \mathrm{~N}$ ), neuronal progenitors (Fig. $8 \mathrm{O}$ ), and astrocytes (Fig. $8 Q$ ) were comparable between WT mice and T1KO mice. However, the promotion ratios of $\mathrm{EE}$ in newborn granule cells were lower in T1KO mice than in WT mice (Fig. $8 P$ ).

\section{Differential localization of CSPG around $\mathrm{PV}^{+}, \mathrm{BLBP}^{+}$, or}

\section{$\mathrm{DCX}^{+}$cells in T1KO mice}

We examined the effect of genetic deletion of CSGalNAcT1 and $\mathrm{EE}$ on the coverage of $\mathrm{PV}^{+}$cells, $\mathrm{BLBP}^{+}$cells, and $\mathrm{DCX}^{+}$cells by $\mathrm{WFA}^{+}$CSPG (Fig. 9). For comparison purposes, we also analyzed chABC-treated WT mice housed in standard conditions: chABC (STD) mice. The coverage of $\mathrm{PV}^{+}$cells by WFA ${ }^{+}$CSPG appeared similar among WT (STD) mice, T1KO (STD) mice, WT (EE) mice, and T1KO (EE) mice, although it was almost undetectable in chABC (STD) mice (Fig. 9A-E). By contrast, the coverage of $\mathrm{BLBP}^{+}$cells by WFA ${ }^{+}$CSPG appeared reduced in 


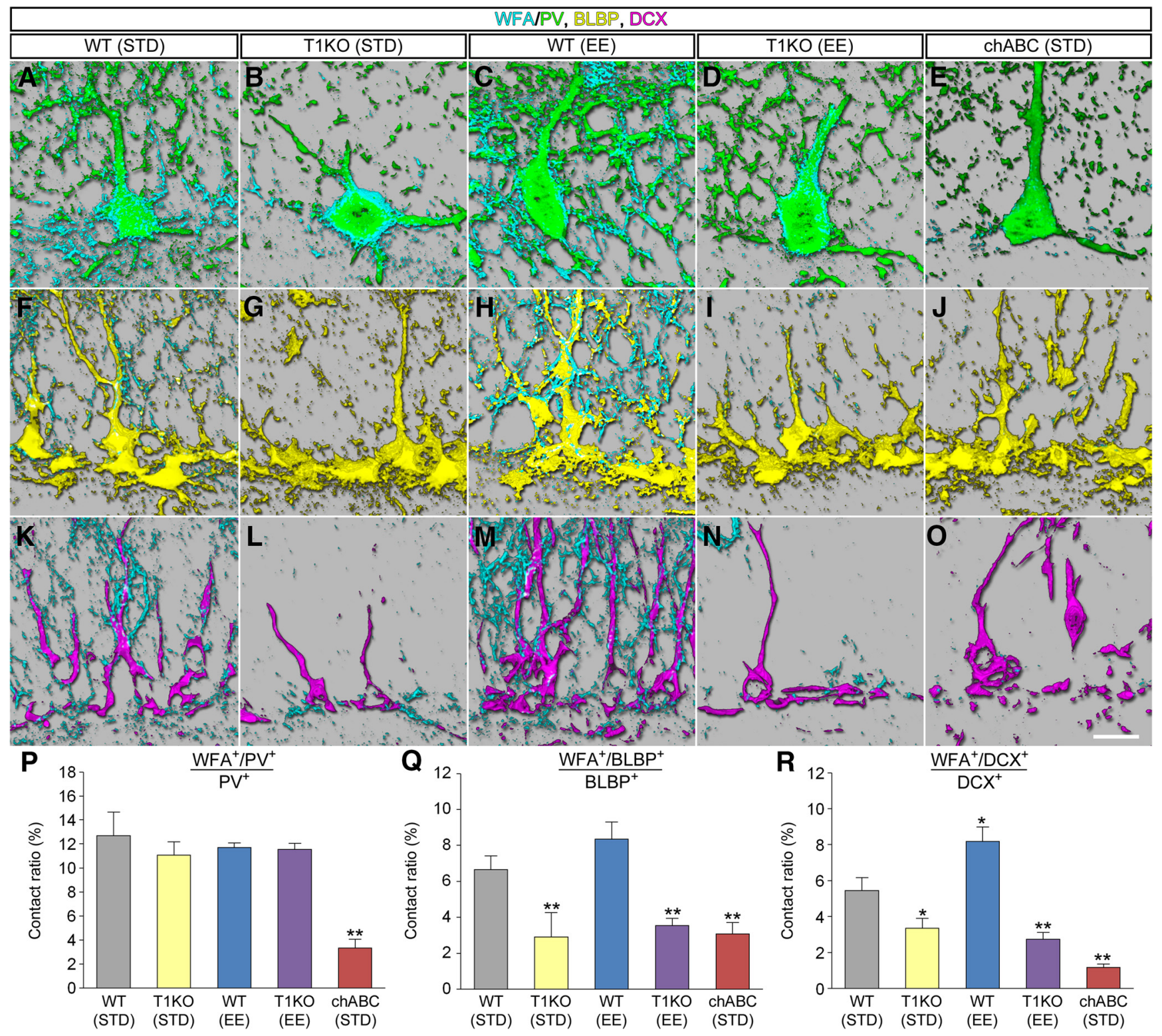

Figure 9. Localizations of CSPG in the dentate gyrus of T1KO mice. $\boldsymbol{A}-\boldsymbol{E}, \mathrm{WFA}{ }^{+}$CSPG (cyan) around PV ${ }^{+}$cells (green) in the dentate gyrus of WT (STD) mice (A), T1KO (STD) mice (B), WT (EE) mice $(\boldsymbol{C})$, T1KO (EE) mice (D), and chABC (STD) mice (E). $\boldsymbol{F}-J$, WFA $^{+}$CSPG (cyan) around BLBP ${ }^{+}$cells (yellow) in the dentate gyrus of WT (STD) mice (F), T1KO (STD) mice (G), WT (EE) mice (H), T1KO (EE) mice $(\boldsymbol{I})$, and chABC (STD) mice $(\boldsymbol{J})$. $\boldsymbol{K}-\mathbf{0}, \mathrm{WFA}^{+}$CSPG (cyan) around DCX ${ }^{+}$cells (magenta) in the dentate gyrus of WT (STD) mice (K), T1K0 (STD) mice (L), WT (EE) mice ( $\left.\boldsymbol{M}\right)$, T1KO (EE) mice ( $\boldsymbol{N}$ ), and chABC (STD) mice (0).P, The proportions (percentage) of WFA ${ }^{+} / \mathrm{PV}^{+}$voxels in total $\mathrm{PV}^{+}$voxels in the granule cell layer $\left(F_{(4,10)}=33.0314, p<0.0001\right) . \boldsymbol{Q}$, The proportions (percentage) of $\mathrm{WFA}^{+} / \mathrm{BLBP}^{+}$voxels in total BLBP ${ }^{+}$voxels in the granule cell layer $\left(F_{(4,10)}=24.921, p<0.0001\right) . \boldsymbol{R}$, The proportions (percentage) of WFA ${ }^{+} / \mathrm{DCX}^{+}$voxels in total $D C X^{+}$voxels in the granule cell layer $\left(F_{(4,10)}=82.1291, p<0.0001\right)$. Data were analyzed by one-way ANOVA with post hoc Tukey's HSD test and are shown as mean \pm SD $(n=3$ mice in each group). Statistical significance:

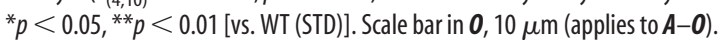

T1KO (STD) mice, T1KO (EE) mice, and chABC (STD) mice (Fig. 9F-J). Similar changes were seen in the coverage of $\mathrm{DCX}^{+}$ cells by WFA ${ }^{+}$CSPG (Fig. 9K-O).

To compare quantitatively the contact between $\mathrm{PV}^{+}, \mathrm{BLBP}^{+}$ or $\mathrm{DCX}^{+}$cells and $\mathrm{WFA}^{+}$CSPG, the ratios (percentage) were calculated by dividing the numbers of $\mathrm{WFA}^{+} / \mathrm{PV}^{+}\left(\right.$or $\mathrm{WFA}^{+} /$ $\mathrm{BLBP}^{+}$or $\mathrm{WFA}^{+} / \mathrm{DCX}^{+}$) voxels by the total numbers of $\mathrm{PV}^{+}$ (or $\mathrm{BLBP}^{+}$or $\mathrm{DCX}^{+}$) voxels (Fig. $9 P-R$ ). The contact ratios between $\mathrm{PV}^{+}$cells and WFA ${ }^{+}$CSPG were similar among groups except for chABC (STD) mice (Fig. 9P). The contact ratios between $\mathrm{BLBP}^{+}$cells and $\mathrm{WFA}^{+}{ }^{+} \mathrm{CSPG}$ were lower in T1KO (STD) mice, T1KO (EE) mice, and chABC (STD) mice than in WT (STD) mice (Fig. 9Q). Similar results were seen in the contact between $\mathrm{WFA}^{+}$CSPG and DCX ${ }^{+}$cells (Fig. 9R).

\section{Lack of effects of EE on cognitive memory in T1KO mice}

The involvement of CSGalNAcT1 in improvement of cognitive memory by EE was measured by NORT. During the familiarization session, all experimental groups showed no difference in time spent exploring the object 1 and 2 (Fig. 10A). Then, during the test session, WT (STD) mice, WT(EE) mice, T1KO (STD) mice, and T1KO(EE) mice explored the novel object longer than the unchanged object, although such preference was not observed in chABC (STD) mice (Fig. 10B).

We then calculated the discrimination index (Fig. 10C). The indices were higher in WT (EE) mice than in WT (STD) mice and lower in chABC (EE) mice than in WT (STD) mice. On the other hand, there were no significant differences in the indices between WT (STD) mice and T1KO (EE or STD) mice. These results 



WT (EE)
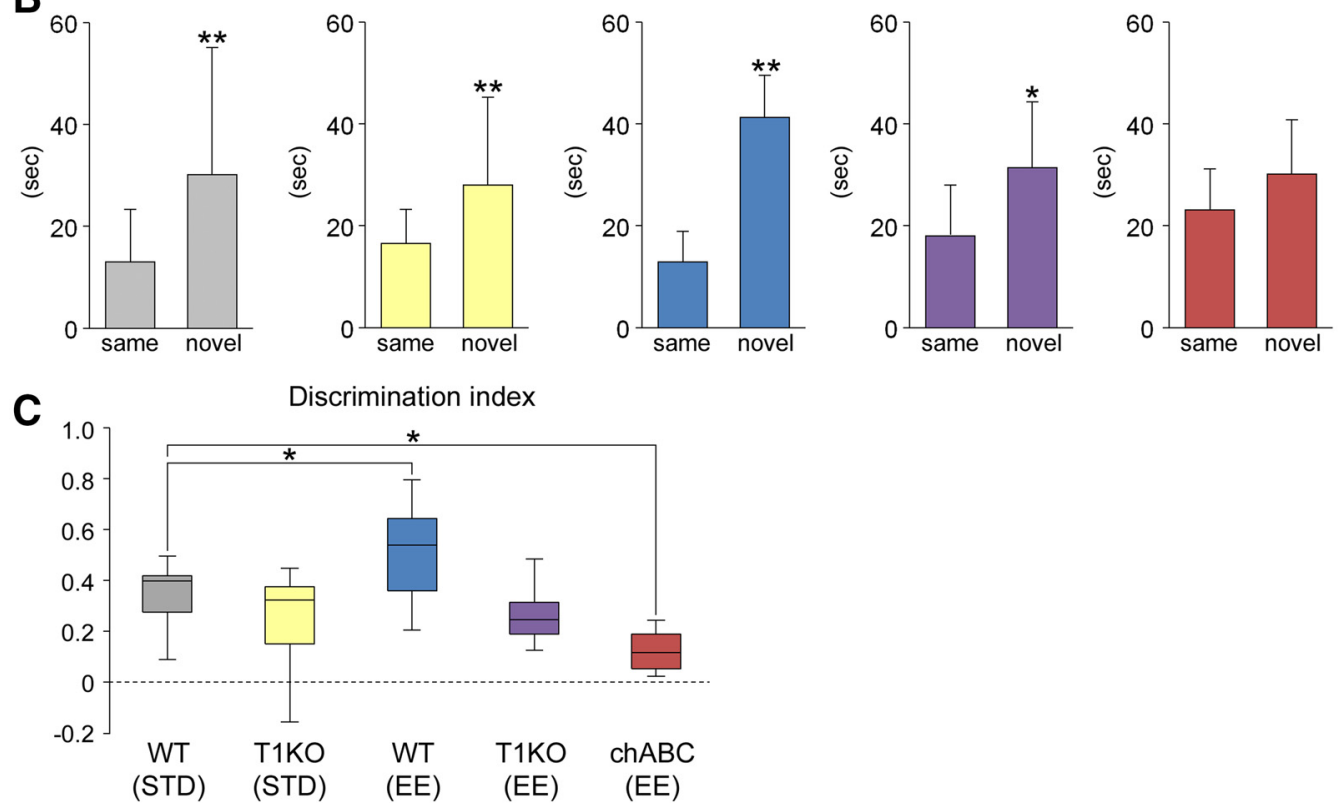

Figure 10. Lack of effects of EE on cognitive memory in T1K0 mice. $A$, Time (in seconds) spent exploring the object 1 and 2 during the familiarization session in WT (STD) mice $(t(23.19)=0.1348$, $p=0.8939)$, T1KO (STD) mice $\left(t_{(23.58)}=0.1907, p=0.8504\right)$, WT (EE) mice $\left(t_{(22.53)}=0.4133, p=0.6833\right)$, T1 KO (EE) mice $\left(t_{(25.95)}=0.0677, p=0.9466\right)$, and chABC (EE) mice $\left(t_{(21.99)}=0.631\right.$, $p=0.5345$ ). Data were analyzed by Welch's $t$ test and are shown as mean \pm SD (WT (STD), $n=13$ mice; T1KO (STD), $n=14$ mice; WT (EE), $n=13$ mice; T1KO (EE), $n=14$ mice; chABC (EE), $n=$ 12 mice). $\boldsymbol{B}$, Time (in seconds) spent exploring the (same and novel) objects during the NORT in WT (STD) mice $\left(t_{(15.91)}=2.2840, p=0.0036\right)$, T1K0 (STD) mice $\left(t_{(16.77)}=2.9229, p=0.0095\right)$, WT (EE) mice $\left(t_{(15.68)}=4.6170, p=0.0003\right)$, T1KO (EE) mice $\left(t_{(22.16)}=2.0779, p=0.0451\right)$, and chABC (EE) mice $\left(t_{(21.67)}=1.008, p=0.3265\right)$. Data were analyzed by Welch's $t$ test and are shown as mean \pm SD (WT (STD), $n=13$ mice; T1KO (STD), $n=14$ mice; WT (EE), $n=13$ mice; T1KO (EE), $n=14$ mice; chABC (EE), $n=12$ mice). C, Using the same dataset, the discrimination indices (time spent with the novel object - time spent with the same object)/(total time exploring both objects) are calculated $\left(F_{(4,61)}=9.7108, p<0.0001\right)$. Discrimination indices of 0 indicate equal exploration of both objects. The central rectangle spans the first quartile to the third quartile. The segment in the rectangle shows the median. The whiskers above and below the box show the locations of the minimum and maximum. Data were analyzed by one-way ANOVA with post hoc Tukey's HSD test. Statistical significance: ${ }^{*} p<0.05,{ }^{* *} p<0.01$ [vs. same for $\boldsymbol{B}$; vs. WT (STD) for $\boldsymbol{C}$.

indicate a lack of effect of EE on cognitive memory by genetic deletion of CSGalNAcT1.

\section{Discussion}

\section{CSPG is involved in production and maturation of granule} cells in the adult hippocampus

In the present study, we showed that neural stem cells, neuronal progenitors, and newborn granule cells in the dentate gyrus were partially covered by $\mathrm{WFA}^{+}$CSPG. It has been indicated that CSPG may be involved in proliferation of neural stem cells and neuronal progenitors as a neurogenic niche in the embryonic brain (Purushothaman et al., 2012). For example, generation of embryonic neurospheres was inhibited by the removal of CSPG by chABC (von Holst et al., 2006). The digestion of CSPG by chABC resulted in reduced proliferation of neural stem cells in the mouse embryo at embryonic days 13-14 (Sirko et al., 2007). However, few studies have addressed the involvement of CSPG in adult hippocampal neurogenesis.

Unexpectedly, here, we found that pharmacological depletion of CSPG in the dentate gyrus decreased the densities of neuronal progenitors and newborn granule cells, whereas the densities of neural stem cells were not affected. Although future studies will be required, our results suggest that self-renewal of neural stem cells may be independent of CSPG, whereas differentiation into neuronal progenitors from neural stem cells and production of newborn granule cells may be mediated by CSPG.

The present 3D reconstruction analysis showed that pharmacological depletion of CSPG in the dentate gyrus impaired the maturation of newborn granule cells. It has been reported that CSPG binds to various neurotrophic factors, such as fibroblast growth factor-2 (FGF-2) and brain-derived neurotrophic factor (BDNF) (Karumbaiah et al., 2015). Together, these findings suggest that CSPG around newborn granule cells may promote their maturation by binding to various neurotrophic factors.

Our Western blot analysis demonstrated that digestion of CSPG in the dentate gyrus resulted in reduction of expression of $\beta$-catenin, whereas the expression of Wnt-3 was unchanged. Previous studies have shown that Wnt signaling inhibits the selfrenewal capacity of cortical neural stem cells and supports their 
neuronal differentiation (Hirabayashi et al., 2004). In addition, $\beta$-catenin controls the downstream of canonical Wnt signaling to regulate the production of appropriate numbers of neuronal progenitors, neuronal subpopulations, and astrocytes (Draganova et al., 2015). Interestingly, CSPG is involved in $\mathrm{Wnt} / \beta$-catenin signaling (Prinz et al., 2014). For instance, a specific structure of CSPG binds to Wnt-3 with high affinity, and serves as "glue" for Wnt-3. Particularly, CSPG containing E-disaccharide units concentrates Wnt-3 molecules on the surface of Wnt-producing cells and enhance Wnt-3 signaling (Nadanaka et al., 2008). We thus hypothesize that loss of CSPG may cause the reduction in concentration of Wnt- 3 on the cell surface, but such subtle change in Wnt-3 distribution may be undetectable by Western blot. Together, these findings suggest that loss of CSPG serving as "glue" for Wnt-3 on the surface of neural stem cells and neuronal progenitors may cause the downregulation of $\beta$-catenin and reduction in granule cell production.

Although chABC injection into the embryonic brain led to an increase in astrocytes during development (Sirko et al., 2007), our experiment showed that injection of chABC into the adult dentate gyrus caused no changes in the densities of astrocytes. In this regard, several studies indicated that neural stem cell divisions may differ between the developing and adult brain (Urbán and Guillemot, 2014). For example, embryonic daughter cells retain stem cell properties upon asymmetric division, as well as molecules that promote proliferation during development. However, in the adult brain, daughter cells lose proproliferative signals because their long-term maintenance depends on their ability to return to a quiescent state (Bonaguidi et al., 2011). It is possible to hypothesize that the differentiation of daughter cells into astrocytes is inhibited by CSPG in the developing brain, but not in the adult brain.

\section{Promotion of adult hippocampal neurogenesis by EE is mediated by CSPG}

Since the discovery of promotion of adult hippocampal neurogenesis by EE (Kempermann et al., 1997), a number of studies have tried to identify the molecular mediators of environmentally enhanced neurogenesis (Eisinger and Zhao, 2018). The present HPLC analysis demonstrated that the amount of CSPG in the dentate gyrus was increased by EE and was decreased by forced swim stress. In addition, EE accelerated the recovery of expression of CSPG in the dentate gyrus from the pharmacological depletion and promoted restoration of the production of granule cells. Although several studies have reported that expression of CSPG in several brain areas may also be modulated by the experiences of animals (Hilbig et al., 2002), the present study is the first to show that increased synthesis of CSPG may be involved in promotion of adult hippocampal neurogenesis by EE.

To understand the mechanisms underlying the alterations in CSPG expression by EE, we analyzed T1KO mice that lacked CSGalNAcT-1, a key enzyme for CSPG synthesis. It has been shown that CSGalNAcT-1 plays a key role in initiation and elongation of side chain of CSPG substrate (Gotoh et al., 2002). Here, we found that expression of CSPG in the dentate gyrus was very low in T1KO mice. In addition, the expression of CSPG in the dentate gyrus was not elevated by EE in these animals and the densities of newborn granule cells were also not increased by EE. These findings indicate that increased synthesis of CSPG by CSGalNAcT1 in the dentate gyrus may be critical for granule cell production in response to EE.

\section{Involvement of CSGalNAcT1 in enhancement of cognitive memory by $\mathrm{EE}$}

It has been reported that the hippocampus is involved in regulation of open-field behaviors (Rossi-Arnaud and AmmassariTeule, 1992; Puschban et al., 2016). Here, we examined the effects of digestion of CSPG in the dentate gyrus on mouse behaviors by OFT. The total distance traveled was recorded as a measure for locomotor activity and the time spent in the center area of the open field was recorded as a measure for anxiety-related behavior (Crawley, 1999). Although we found here that the locomotor activity was not affected by CSPG digestion, the effects of suppression of adult hippocampal neurogenesis on locomotor activity remain rather controversial. For instance, cranial irradiation accompanying inhibition of adult hippocampal neurogenesis increased the locomotor activity (Roughton et al., 2012). Genetic ablation of neural progenitors caused reduction in locomotor activity in transgenic Gfap-tk mice (Sakalem et al., 2017). We also found that the anxiety-related behavior was also not affected by CSPG digestion. The present results may be consistent with previous reports showing no effect of neurogenesis ablation on anxiety-related behaviors (Shors et al., 2002; Saxe et al., 2006), although there is another view (Hill et al., 2015). Together, these results indicate that modulation of adult hippocampal neurogenesis by CSPG may not be involved in anxiety-related behavior and locomotor activity, although further studies are needed to fully understand our findings.

It has been shown that $\mathrm{T} 1 \mathrm{KO}$ mice exhibit several abnormal behaviors that involve higher-order brain functions (Yoshioka et al., 2017). In this study, we focused on the alterations in cognitive memory in T1KO mice using NORT (Broadbent et al., 2010), because recent studies have reported that $\mathrm{EE}$ and exercise increase adult hippocampal neurogenesis and improve hippocampaldependent cognitive memory (Bruel-Jungerman et al., 2005; Bechara and Kelly, 2013; Bolz et al., 2015). The discrimination index was not improved by EE in T1KO mice. Consistent with this result, the expression of WFA in the dentate gyrus was also not increased by EE in T1KO mice. Because WFA mainly recognizes CS-4, these findings suggest that increased synthesis of CSPG (CS-4) by CSGalNAcT1 in the dentate gyrus may be required for improvement of cognitive memory in response to $\mathrm{EE}$.

Finally, cognitive memory was normal in T1KO mice housed in standard conditions, whereas it was impaired in chABCtreated mice. Although it is difficult to fully explain this discrepancy, there are several points to be discussed. First, in standard conditions, the densities of neuronal progenitors remained unchanged in T1KO mice (decreased by $6 \%$ compared with WT mice), whereas they were severely declined in chABC-treated mice (decreased by $52 \%$ compared with P-ase-treated mice). The reduction rates of newborn granule cells were larger in chABCtreated mice (decreased by $66 \%$ compared with $\mathrm{P}$-ase-treated mice) than in T1KO mice (decreased by $28 \%$ compared with WT mice). A previous study has reported a level-dependent inhibitory effect of adult hippocampal neurogenesis on cognitive memory (Jessberger et al., 2009). Relatively weak suppression of adult neurogenesis may underlie the preservation of cognitive memory in T1KO mice. Second, $\mathrm{WFA}^{+}$PNNs around $\mathrm{PV}^{+}$neurons are depleted in chABC-treated mice, whereas they are spared in T1KO mice. Because it has been shown that $\mathrm{PV}^{+}$neurons promote newborn granule cell survival and development (Song et al., 2013), preservation of $\mathrm{WFA}^{+}$PNNs around $\mathrm{PV}^{+}$neurons may also underlie $\mathrm{PV}^{+}$neuron-dependent adult hippocampal neurogenesis in T1KO mice. Regardless, the lack of effects of EE in 
T1KO mice indicates that WFA ${ }^{+}$PNNs may not mediate promotion of adult hippocampal neurogenesis in response to EE.

\section{References}

Akita K, von Holst A, Furukawa Y, Mikami T, Sugahara K, Faissner A (2008) Expression of multiple chondroitin/dermatan sulfotransferases in the neurogenic regions of the embryonic and adult central nervous system implies that complex chondroitin sulfates have a role in neural stem cell maintenance. Stem Cells 26:798-809. CrossRef Medline

Altman J, Das GD (1967) Postnatal neurogenesis in the guinea-pig. Nature 214:1098-1101. CrossRef Medline

Bechara RG, Kelly ÁM (2013) Exercise improves object recognition memory and induces BDNF expression and cell proliferation in cognitively enriched rats. Behav Brain Res 245:96-100. CrossRef Medline

Bolz L, Heigele S, Bischofberger J (2015) Running improves pattern separation during novel object recognition. Brain Plast 1:129-141. CrossRef Medline

Bonaguidi MA, Wheeler MA, Shapiro JS, Stadel RP, Sun GJ, Ming GL, Song H (2011) In vivo clonal analysis reveals self-renewing and multipotent adult neural stem cell characteristics. Cell 145:1142-1155. CrossRef Medline

Bordey A (2006) Adult neurogenesis: basic concepts of signaling. Cell Cycle 5:722-728. CrossRef Medline

Brandt MD, Jessberger S, Steiner B, Kronenberg G, Reuter K, Bick-Sander A, von der Behrens W, Kempermann G (2003) Transient calretinin expression defines early postmitotic step of neuronal differentiation in adult hippocampal neurogenesis of mice. Mol Cell Neurosci 24:603-613. CrossRef Medline

Broadbent NJ, Gaskin S, Squire LR, Clark RE (2010) Object recognition memory and the rodent hippocampus. Learn Mem 17:5-11. CrossRef Medline

Brown JP, Couillard-Després S, Cooper-Kuhn CM, Winkler J, Aigner L, Kuhn HG (2003) Transient expression of doublecortin during adult neurogenesis. J Comp Neurol 467:1-10. CrossRef Medline

Brückner G, Seeger G, Brauer K, Härtig W, Kacza J, Bigl V (1994) Cortical areas are revealed by distribution patterns of proteoglycan components and parvalbumin in the Mongolian gerbil and rat. Brain Res 658:67-86. CrossRef Medline

Bruel-Jungerman E, Laroche S, Rampon C (2005) New neurons in the dentate gyrus are involved in the expression of enhanced long-term memory following environmental enrichment. Eur J Neurosci 21:513-521. CrossRef Medline

Cameron HA, Woolley CS, McEwen BS, Gould E (1993) Differentiation of newly born neurons and glia in the dentate gyrus of the adult rat. Neuroscience 56:337-344. CrossRef Medline

Contestabile A, Greco B, Ghezzi D, Tucci V, Benfenati F, Gasparini L (2013) Lithium rescues synaptic plasticity and memory in down syndrome mice. J Clin Invest 123:348-361. CrossRef Medline

Crawley JN (1999) Behavioral phenotyping of transgenic and knockout mice: experimental design and evaluation of general health, sensory functions, motor abilities, and specific behavioral tests. Brain Res 835:18-26. CrossRef Medline

Czéh B, Welt T, Fischer AK, Erhardt A, Schmitt W, Müller MB, Toschi N, Fuchs E, Keck ME (2002) Chronic psychosocial stress and concomitant repetitive transcranial magnetic stimulation: effects on stress hormone levels and adult hippocampal neurogenesis. Biol Psychiatry 52:10571065. CrossRef Medline

Deepa SS, Umehara Y, Higashiyama S, Itoh N, Sugahara K (2002) Specific molecular interactions of oversulfated chondroitin sulfate $\mathrm{E}$ with various heparin-binding growth factors: implications as a physiological binding partner in the brain and other tissues. J Biol Chem 277:43707-43716. CrossRef Medline

Draganova K, Zemke M, Zurkirchen L, Valenta T, Cantù C, Okoniewski M, Schmid MT, Hoffmans R, Götz M, Basler K, Sommer L (2015) Wnt/ beta-catenin signaling regulates sequential fate decisions of murine cortical precursor cells. Stem Cells 33:170-182. CrossRef Medline

Dupret D, Fabre A, Döbrössy MD, Panatier A, Rodríguez JJ, Lamarque S, Lemaire V, Oliet SH, Piazza PV, Abrous DN (2007) Spatial learning depends on both the addition and removal of new hippocampal neurons. PLoS Biol 5:e214. CrossRef Medline

Eisinger BE, Zhao X (2018) Identifying molecular mediators of environ- mentally enhanced neurogenesis. Cell Tissue Res 371:7-21. CrossRef Medline

Gage FH (2000) Mammalian neural stem cells. Science 287:1433-1438. CrossRef Medline

Gotoh M, Sato T, Akashima T, Iwasaki H, Kameyama A, Mochizuki H, Yada T, Inaba N, Zhang Y, Kikuchi N, Kwon YD, Togayachi A, Kudo T, Nishihara S, Watanabe H, Kimata K, Narimatsu H (2002) Enzymatic synthesis of chondroitin with a novel chondroitin sulfate N-acetylgalactosaminyltransferase that transfers $\mathrm{N}$-acetylgalactosamine to glucuronic acid in initiation and elongation of chondroitin sulfate synthesis. J Biol Chem 277:38189-38196. CrossRef Medline

Gundersen HJ, Jensen EB, Kiêu K, Nielsen J (1999) The efficiency of systematic sampling in stereology-reconsidered. J Microsc 193:199-211. CrossRef Medline

Hilbig H, Bidmon HJ, Steingrüber S, Reinke H, Dinse HR (2002) Enriched environmental conditions reverse age-dependent gliosis and losses of neurofilaments and extracellular matrix components but do not alter lipofuscin accumulation in the hindlimb area of the aging rat brain. J Chem Neuroanat 23:199-209. CrossRef Medline

Hill AS, Sahay A, Hen R (2015) Increasing adult hippocampal neurogenesis is sufficient to reduce anxiety and depression-like behaviors. Neuropsychopharmacology 40:2368-2378. CrossRef Medline

Hirabayashi Y, Itoh Y, Tabata H, Nakajima K, Akiyama T, Masuyama N, Gotoh Y (2004) The Wnt/beta-catenin pathway directs neuronal differentiation of cortical neural precursor cells. Development 131:2791-2801. CrossRef Medline

Jessberger S, Clark RE, Broadbent NJ, Clemenson GD Jr, Consiglio A, Lie DC, Squire LR, Gage FH (2009) Dentate gyrus-specific knockdown of adult neurogenesis impairs spatial and object recognition memory in adult rats. Learn Mem 16:147-154. CrossRef Medline

Jinno S, Aika Y, Fukuda T, Kosaka T (1998) Quantitative analysis of GABAergic neurons in the mouse hippocampus, with optical disector using confocal laser scanning microscope. Brain Res 814:55-70. CrossRef Medline

Kaplan MS, Hinds JW (1977) Neurogenesis in the adult rat: electron microscopic analysis of light radioautographs. Science 197:1092-1094. CrossRef Medline

Karumbaiah L, Enam SF, Brown AC, Saxena T, Betancur MI, Barker TH, Bellamkonda RV (2015) Chondroitin sulfate glycosaminoglycan hydrogels create endogenous niches for neural stem cells. Bioconjug Chem 26:2336-2349. CrossRef Medline

Kazanis I, ffrench-Constant C (2011) Extracellular matrix and the neural stem cell niche. Dev Neurobiol 71:1006-1017. CrossRef Medline

Kempermann G, Gage FH (1999) Experience-dependent regulation of adult hippocampal neurogenesis: effects of long-term stimulation and stimulus withdrawal. Hippocampus 9:321-332. CrossRef Medline

Kempermann G, Kuhn HG, Gage FH (1997) More hippocampal neurons in adult mice living in an enriched environment. Nature 386:493-495. CrossRef Medline

Kriegstein A, Alvarez-Buylla A (2009) The glial nature of embryonic and adult neural stem cells. Annu Rev Neurosci 32:149-184. CrossRef Medline

Leger M, Quiedeville A, Bouet V, Haelewyn B, Boulouard M, Schumann-Bard P, Freret T (2013) Object recognition test in mice. Nat Protoc 8:25312537. CrossRef Medline

Michelacci YM, Dietrich CP (1975) A comparative study between a chondroitinase $\mathrm{B}$ and a chondroitinase $\mathrm{AC}$ from flavobacterium heparinum: isolation of a chondroitinase AC-susceptible dodecasaccharide from chondroitin sulphate B. Biochem J 151:121-129. CrossRef Medline

Miyata S, Kitagawa H (2016) Chondroitin 6-sulfation regulates perineuronal net formation by controlling the stability of aggrecan. Neural Plast 2016:1305801. CrossRef Medline

Miyata S, Komatsu Y, Yoshimura Y, Taya C, Kitagawa H (2012) Persistent cortical plasticity by upregulation of chondroitin 6-sulfation. Nat Neurosci 15:414-422, S1-S2. CrossRef Medline

Mizoguchi K, Ishige A, Aburada M, Tabira T (2003) Chronic stress attenuates glucocorticoid negative feedback: involvement of the prefrontal cortex and hippocampus. Neuroscience 119:887-897. CrossRef Medline

Nadanaka S, Ishida M, Ikegami M, Kitagawa H (2008) Chondroitin 4-Osulfotransferase-1 modulates wnt-3a signaling through control of E disaccharide expression of chondroitin sulfate. J Biol Chem 283:27333-27343. CrossRef Medline

Nakamura M, Nakano K, Morita S, Nakashima T, Oohira A, Miyata S (2009) 
Expression of chondroitin sulfate proteoglycans in barrel field of mouse and rat somatosensory cortex. Brain Res 1252:117-129. CrossRef Medline

Opendak M, Gould E (2015) Adult neurogenesis: a substrate for experiencedependent change. Trends Cogn Sci 19:151-161. CrossRef Medline

Petrik D, Lagace DC, Eisch AJ (2012) The neurogenesis hypothesis of affective and anxiety disorders: are we mistaking the scaffolding for the building? Neuropharmacology 62:21-34. CrossRef Medline

Pham K, Nacher J, Hof PR, McEwen BS (2003) Repeated restraint stress suppresses neurogenesis and induces biphasic PSA-NCAM expression in the adult rat dentate gyrus. Eur J Neurosci 17:879-886. CrossRef Medline

Pizzorusso T, Medini P, Berardi N, Chierzi S, Fawcett JW, Maffei L (2002) Reactivation of ocular dominance plasticity in the adult visual cortex. Science 298:1248-1251. CrossRef Medline

Prinz RD, Willis CM, van Kuppevelt TH, Klüppel M (2014) Biphasic role of chondroitin sulfate in cardiac differentiation of embryonic stem cells through inhibition of Wnt/beta-catenin signaling. PLoS One 9:e92381. CrossRef Medline

Purushothaman A, Sugahara K, Faissner A (2012) Chondroitin sulfate "wobble motifs" modulate maintenance and differentiation of neural stem cells and their progeny. J Biol Chem 287:2935-2942. CrossRef Medline

Puschban Z, Sah A, Grutsch I, Singewald N, Dechant G (2016) Reduced anxiety-like behavior and altered hippocampal morphology in female p75NTR(exon IV-/-) mice. Front Behav Neurosci 10:103. CrossRef Medline

Rossi-Arnaud C, Ammassari-Teule M (1992) Modifications of open field and novelty behaviours by hippocampal and amygdaloid lesions in two inbred strains of mice: lack of strain x lesion interactions. Behav Processes 27:155-164. CrossRef Medline

Roughton K, Kalm M, Blomgren K (2012) Sex-dependent differences in behavior and hippocampal neurogenesis after irradiation to the young mouse brain. Eur J Neurosci 36:2763-2772. CrossRef Medline

Sakalem ME, Seidenbecher T, Zhang M, Saffari R, Kravchenko M, Wördemann S, Diederich K, Schwamborn JC, Zhang W, Ambrée O (2017) Environmental enrichment and physical exercise revert behavioral and electrophysiological impairments caused by reduced adult neurogenesis. Hippocampus 27:36-51. CrossRef Medline

Sato T, Kudo T, Ikehara Y, Ogawa H, Hirano T, Kiyohara K, Hagiwara K, Togayachi A, Ema M, Takahashi S, Kimata K, Watanabe H, Narimatsu H (2011) Chondroitin sulfate $\mathrm{N}$-acetylgalactosaminyltransferase 1 is necessary for normal endochondral ossification and aggrecan metabolism. J Biol Chem 286:5803-5812. CrossRef Medline

Saxe MD, Battaglia F, Wang JW, Malleret G, David DJ, Monckton JE, Garcia AD, Sofroniew MV, Kandel ER, Santarelli L, Hen R, Drew MR (2006) Ablation of hippocampal neurogenesis impairs contextual fear conditioning and synaptic plasticity in the dentate gyrus. Proc Natl Acad Sci U S A 103:17501-17506. CrossRef Medline

Schindelin J, Arganda-Carreras I, Frise E, Kaynig V, Longair M, Pietzsch T, Preibisch S, Rueden C, Saalfeld S, Schmid B, Tinevez JY, White DJ, Hartenstein V, Eliceiri K, Tomancak P, Cardona A (2012) Fiji: an opensource platform for biological-image analysis. Nat Methods 9:676-682. CrossRef Medline
Seaberg RM, van der Kooy D (2003) Stem and progenitor cells: the premature desertion of rigorous definitions. Trends Neurosci 26:125-131. CrossRef Medline

Sholl DA (1953) Dendritic organization in the neurons of the visual and motor cortices of the cat. J Anat 87:387-406. Medline

Shors TJ, Miesegaes G, Beylin A, Zhao M, Rydel T, Gould E (2001) Neurogenesis in the adult is involved in the formation of trace memories. Nature 410:372-376. CrossRef Medline

Shors TJ, Townsend DA, Zhao M, Kozorovitskiy Y, Gould E (2002) Neurogenesis may relate to some but not all types of hippocampal-dependent learning. Hippocampus 12:578-584. CrossRef Medline

Sirko S, von Holst A, Wizenmann A, Götz M, Faissner A (2007) Chondroitin sulfate glycosaminoglycans control proliferation, radial glia cell differentiation and neurogenesis in neural stem/progenitor cells. Development 134:2727-2738. CrossRef Medline

Song J, Sun J, Moss J, Wen Z, Sun GJ, Hsu D, Zhong C, Davoudi H, Christian KM, Toni N, Ming GL, Song H (2013) Parvalbumin interneurons mediate neuronal circuitry-neurogenesis coupling in the adult hippocampus. Nat Neurosci 16:1728-1730. CrossRef Medline

Spradling A, Drummond-Barbosa D, Kai T (2001) Stem cells find their niche. Nature 414:98-104. CrossRef Medline

Taupin P (2007) BrdU immunohistochemistry for studying adult neurogenesis: paradigms, pitfalls, limitations, and validation. Brain Res Rev 53:198-214. CrossRef Medline

Urbán N, Guillemot F (2014) Neurogenesis in the embryonic and adult brain: same regulators, different roles. Front Cell Neurosci 8:396. CrossRef Medline

von Holst A, Sirko S, Faissner A (2006) The unique 473HD-chondroitinsulfate epitope is expressed by radial glia and involved in neural precursor cell proliferation. J Neurosci 26:4082-4094. CrossRef Medline

Watanabe Y, Takeuchi K, Higa Onaga S, Sato M, Tsujita M, Abe M, Natsume R, Li M, Furuichi T, Saeki M, Izumikawa T, Hasegawa A, Yokoyama M, Ikegawa S, Sakimura K, Amizuka N, Kitagawa H, Igarashi M (2010) Chondroitin sulfate $\mathrm{N}$-acetylgalactosaminyltransferase- 1 is required for normal cartilage development. Biochem J 432:47-55. CrossRef Medline

West MJ, Slomianka L, Gundersen HJ (1991) Unbiased stereological estimation of the total number of neurons in thesubdivisions of the rat hippocampus using the optical fractionator. Anat Rec 231:482-497. CrossRef Medline

Yamada J, Ohgomori T, Jinno S (2015) Perineuronal nets affect parvalbumin expression in GABAergic neurons of the mouse hippocampus. Eur J Neurosci 41:368-378. CrossRef Medline

Yamada J, Hatabe J, Tankyo K, Jinno S (2016) Cell type- and region-specific enhancement of adult hippocampal neurogenesis by daidzein in middleaged female mice. Neuropharmacology 111:92-106. CrossRef Medline

Yoshioka N, Miyata S, Tamada A, Watanabe Y, Kawasaki A, Kitagawa H, Takao K, Miyakawa T, Takeuchi K, Igarashi M (2017) Abnormalities in perineuronal nets and behavior in mice lacking CSGalNAcT1, a key enzyme in chondroitin sulfate synthesis. Mol Brain 10:47. CrossRef Medline 